\title{
ARTIKEL
}

\section{Derdeninterventie bij collectieve arbeidsconflicten na de Wnra}

\section{Het 'vergeten' derde lid van artikel $6 \mathrm{ESH}^{*}$}

\author{
N. Hummel
}

1

Inleiding

Als we de media mogen geloven, zijn de arbeidsverhoudingen in Nederland conflictrijker geworden, met koppen als 'Werknemers durven weer op de barricaden' en 'Nederland schuwt het staken niet meer'. ${ }^{1}$ Hoewel de conclusie dat Nederland een 'stakingsland' is enigszins voorbarig lijkt, ${ }^{2}$ blijkt uit cijfers van het CBS wel dat de afgelopen jaren meer is gestaakt dan voorheen. ${ }^{3}$ In 2019 was een recordaantal werknemers betrokken bij een staking, vooral door grote stakingen in het onderwijs en in de zorg. Het (te vaak) hanteren van het stakingswapen heeft echter ook een keerzijde. De publieke opinie kan zich tegen de actievoerders keren, niet in de laatste plaats vanwege de economische schade die ermee gepaard kan gaan. ${ }^{4}$ Essentiële diensten, zoals het openbaar vervoer, de gezondheidszorg, brandweer en politie, lopen bovendien relatief snel op tegen een beperking van of verbod op een voorgenomen actie; voor militairen geldt zelfs een stakingsverbod (artikel 12i Wet ambtenaren defensie (Wad)). Wat dan te doen als polderen niet meer werkt? Een aantrekkelijk alternatief lijkt verzoening, bemiddeling of arbitrage, waarbij een derde wordt betrokken om partijen nader tot elkaar te brengen ('derdeninterventie'). ${ }^{5}$ Bij succes kan een collectieve actie worden voorkomen. Ander voordeel is dat een buitenstaander de emoties uit het geschil kan halen, hetgeen de overlegverhoudingen ten goede komt: cao-partijen zijn nu eenmaal

* N. (Nataschja) Hummel is als docent/onderzoeker verbonden aan de Universiteit Utrecht.

1 Werknemers durven weer op de barricaden, ad.nl 20 augustus 2018; Nederland schuwt het staken niet meer, De Limburger 24 juni 2017.

2 We staken steeds meer, maar zijn we een stakingsland?, eenvandaag/avrotros.nl 1 mei 2018.

3 Te raadplegen via cbs.nl/nl-nl/visualisaties/dashboard-arbeidsmarkt/werkenden/werkstakingen. Met name het aantal verloren arbeidsdagen is sterk toegenomen. In 2019 lag het aantal stakingen lager (26) dan in 2017 en 2018.

4 A.T.J.M. Jacobs, Collectief arbeidsrecht, Deventer: Kluwer 2017, par. 7.1. Zie ook: Het hele onderwijs gaat staken: 'Te veel staken werkt averechts', trouw.nl 9 januari 2019.

5 Vormen van derdeninterventie zijn (met aflopende macht van de derde): machtsingreep, arbitrage, gezamenlijke besluitvorming, bemiddeling, verzoening, procesbegeleiding en onderzoek (C.J. Loonstra, Derden-interventie bij cao-conflicten. Grenzen en mogelijkheden van wettelijke regulering (diss. Utrecht), Groningen: Wolters-Noordhoff 1987, hoofdstuk III). 
ook in de toekomst op elkaar aangewezen. ${ }^{6}$ Opvallend is de geringe aandacht voor derdeninterventie bij collectieve arbeidsgeschillen, terwijl bij individuele geschillen mediation de afgelopen jaren juist een grote vlucht heeft genomen, zowel in het private arbeidsrecht als in het ambtenarenrecht. ${ }^{7}$ Dit geldt temeer omdat internationale verdragen, in het bijzonder het Europees Sociaal Handvest (ESH) en de verdragen van de Internationale Arbeidsorganisatie (ILO), ${ }^{8}$ op dit punt verplichtingen bevatten.

In de publieke sector heeft Nederland in 1984 gehoor gegeven aan deze verplichtingen door instelling van de Advies en Arbitragecommissie Rijksdienst (AAC), die de taak heeft om te adviseren en arbitrale uitspraken te doen in geschillen die zich voordoen in het arbeidsvoorwaardenoverleg in de kabinetssectoren (Rijk, Politie, Defensie en Rechterlijke macht). Het doorlopen van de geschillenprocedure is niet verplicht. De AAC past, als extra waarborg voor de continuïteit van de geleverde (essentiële) diensten, bij de bijzondere positie van de overheid. Op 1 januari 2020 is de Wet normalisering rechtspositie ambtenaren (Wnra) in werking getreden, waardoor het gros van de ambtenaren thans onder titel 7.10 van het Burgerlijk Wetboek (BW) is gebracht. ${ }^{9}$ Door de bijbehorende overgang naar het cao-stelsel is de wettelijke grondslag voor de overlegregels niet meer te vinden in de Ambtenarenwet 2017 (AW 2017). Voor de genormaliseerde sectoren betekent dit dus het einde van de AAC als wettelijke voorziening. De keuze om per 1 januari 2020 deze of een vergelijkbare voorziening te treffen is verder overgelaten aan de cao-partijen. ${ }^{10}$ In tegenstelling tot veel andere Europese landen heeft Nederland dit voor de marktsector niet nader geregeld. ${ }^{11}$ Hier staat de auto-

6 Loonstra 1987, p. 20-21; A. de Roo \& R. Jagtenburg, Bij arbeidsconflict is bemiddeling beter dan arbitrage, volkskrant.nl 4 februari 1995.

7 Zie bijvoorbeeld A.M.M.M. Bots, Conflictoplossing via mediation: naar een meer gestructureerd gebruik van mediation in het ambtenarenrecht; mogelijkheden en (enige) knelpunten, TAR 2006/206; A.J.M. Sponselee, Mediation: een strategisch verplichte omweg, AR 2007/48; S.K. Schreurs, Mediation: een strategisch verplichte omweg? Een reactie, AR 2008/10; E. Knipschild, De Pel-vuistregels bij mediation in arbeidsrecht anno 2014, TAP 2014/2, p. 113-117; G. Stouthart, Arbeidsconflicten en mediation, AR 2019/30; de special Alternatieve geschillenbeslechting van TAP (TAP 2019/2). Zie ook de initiatiefwetsvoorstellen Wet bevordering van mediation in het bestuursrecht (Kamerstukken II 2012/13, 33727, nr. 2) en in het burgerlijke recht (Kamerstukken II 2012/13, 33723, nr. 2), die inmiddels zijn ingetrokken (Kamerstukken II 2014/15, 33722, nr. 24). Ter vervanging hiervan is de Wet bevordering mediation in 2016 in consultatie gegeven. Na een kritisch onthaal is de behandeling stil komen te liggen.

8 Eisen op het terrein van derdeninterventie ter beslechting van collectieve arbeidsgeschillen zijn opgenomen in ILO-verdrag 151 en ILO-verdrag 154. Zie ook de aanbeveling van 1981 (nr. 163) inzake collectief onderhandelen. ILO-verdrag 151 ziet specifiek op de vakverenigingsrechten van personen in dienst van de overheid.

9 Wet van 9 maart 2017, Stb. 123. Zie ook B. Barentsen, N. Hummel \& S.F.H. Jellinghaus (red.), Van ambtenaar naar ambtenaar, Weert: Celsus juridische uitgeverij 2018.

10 Zie ook Kamerstukken II 2018/19, 35089, 4, p. 3.

11 A. de Roo \& R. Jagtenburg, Europa in de polder. Over onderhandelen, bemiddeling en arbitrage bij collectieve arbeidsconflicten, TMD 2005/4, p. 79-81; A. de Roo \& R. Jagtenberg, Settling disputes in Europe, Deventer/Boston: Kluwer 1994; L.C.J. Sprengers, CAO bij de overheid: is er nog wel reden voor een apart overlegstelsel bij de overheid?, SR 2005/65, par. 7.1; A.F.M. Brenninkmeijer e.a. (red.), Effective resolution of collective labour disputes, Groningen: Europa Law Publishing 2006. 
nomie van de cao-partijen voorop. ${ }^{12}$ Inmiddels is duidelijk dat de AAC terugkeert in de ambtelijke cao's die op 1 januari 2020 zijn ingegaan. De vraag is echter wat hier de gevolgen van zijn. Is een dergelijke arbitrage-/adviesclausule eigenlijk wel gebruikelijk in de marktsector? Met andere woorden: is hier wel echt sprake van normalisering? En heeft de wijze waarop een voorziening ter beslechting van collectieve arbeidsgeschillen is verwezenlijkt, invloed op (de uitoefening van) het collectief actierecht?

In deze bijdrage wordt in de eerste plaats ingegaan op de rol van de AAC vóór 1 januari 2020 (paragraaf 2) en vervolgens op die ná deze datum, mede in het licht van de wijze waarop derdeninterventie bij cao-conflicten gestalte heeft gekregen in de marktsector (paragraaf 3). Daarna komt de verhouding met het collectief actierecht aan de orde (paragraaf 4). Ten slotte wordt in paragraaf 5 gereflecteerd op de vraag of het raadzaam is de wettelijke regeling van de AAC (al dan niet in aangepaste vorm) te herintroduceren in de sector overheid, of zelfs in de marktsector.

\section{De AAC vóór 1 januari 2020}

\section{$2.1 \quad$ Instelling}

Zoals vermeld, is bij de overheid in 1984 voorzien in een geschillenregeling. Waarom heeft de wetgever er juist in de sector overheid voor gekozen om derdeninterventie bij collectieve conflicten op zich te nemen? Hiervoor zijn twee redenen. In de eerste plaats moest dit de disbalans in de verhouding tussen de overlegpartijen rechttrekken. ${ }^{13}$ De overheid is een bijzondere werkgever, ondanks dat de inwerkingtreding van de Wnra eens temeer duidelijk heeft gemaakt dat de meeste ambtenaren in veel opzichten 'normaal' zijn. Het bijzondere van de overheid als werkgever heeft lange tijd zijn weerslag gehad op de wijze waarop het overleg met de centrales van overheidspersoneel werd gevoerd: het zogenoemde 'georganiseerd overleg'. Tot de jaren tachtig van de vorige eeuw was feitelijk sprake van een 'dicterende overheid': de overheid was verplicht om overleg te voeren met de centrales van overheidspersoneel, maar hoefde geen overeenstemming te bereiken. ${ }^{14}$ Dit werd gerechtvaardigd vanuit de dubbelrol van de overheid als werkgever en wetgever, waardoor geen sprake kon zijn van onderhandelingen tussen twee gelijkwaardige partijen. ${ }^{15}$ Pas na afschaffing van het strafrechtelijk stakingsverbod ${ }^{16}$ werd het cao-stelsel genaderd met de invoering van het overeen-

12 M.G. Rood, Enkele gedachten over final-offer arbitration, in: K.M. Becking e.a. (red.), Final-offer arbitrage, Den Haag:: Sdu Juridische \& Fiscale Uitgeverij 1993, p. 45.

13 Zie ook M.J.W.M. Akkermans, Gelijk hebben en gelijk krijgen. Tien jaar Advies- en Arbitragecommissie Rijksdienst, Den Haag: CAOP 1994, p. 13-14; W. Albeda, Ambtenaren in de toekomst, in: W. Albeda, T.H Dragt \& W.S.P. Fortuyn, Ambtenaren in het jaar 2000, Den Haag: Sdu uitgeverij 1989, p. 166.

14 Besluit van 5 maart 1986, Stb. 1986, 95, p. 6.

15 Kamerstukken II 1964/65, 7834, nr. 2, p. 12.

16 Zie Kamerstukken 11001. Om ratificatie van het ESH te bespoedigen werd in de Goedkeuringswet een als tijdelijk bedoeld voorbehoud gemaakt, waardoor het overheidspersoneel van de werking van artikel 6 lid 4 ESH werd uitgezonderd (Rijkswet 2 november 1978, Stb. 639). 
stemmingsvereiste (1989) en het sectorenmodel (1993) - door de initiatiefnemers van de Wnra dan ook geduid als 'belangrijke stappen in het normaliseringsproces'. ${ }^{17}$

De tweede - directe - aanleiding vormde de ratificatie van het ESH. In artikel 6 lid 3 van dit verdrag verbinden de partijen zich, ter waarborging van het recht op collectief onderhandelen, om 'de instelling en toepassing van een doelmatige procedure voor bemiddeling en vrijwillige arbitrage inzake de beslechting van arbeidsgeschillen te bevorderen'. De Engelse tekst spreekt van 'conciliation and voluntary arbitration'; het Europees Comité voor Sociale Rechten (ECSR), dat ziet op de naleving van het ESH, rekent hieronder verzoening, bemiddeling en vrijwillige arbitrage ${ }^{18}$ In tegenstelling tot arbitrage leidt bemiddeling niet tot een bindend oordeel van een (of meer) derde(n). ${ }^{19}$ Bij bemiddeling begeleidt een derde partijen in het vinden van een oplossing van het geschil en kan, anders dan bij verzoening, zelf voorstellen doen ter beëindiging van het geschil. ${ }^{20}$ De parlementaire behandeling van het ESH leidde tot de instelling van de commissie-Toxopeus II, ${ }^{21}$ die in 1980 advies uitbracht over (1) de regeling van het stakingsrecht van ambtenaren in het licht van artikel 31 (thans G) ESH, en (2) een voorziening inzake het beslechten van arbeidsgeschillen voor de gevallen waarin het overleg niet tot overeenstemming heeft geleid. ${ }^{22}$ Aanleiding voor het eerste advies was artikel 6 lid 4 ESH en het daarbij gemaakte voorbehoud voor het overheidspersoneel, dat als tijdelijk was bedoeld tot artikel $31 \mathrm{ESH}$ was uitgewerkt; ${ }^{23}$ voor het tweede advies was dit artikel 6 lid 3 ESH. Uiteindelijk ${ }^{24}$ kwam het in 1984 tot een voorziening voor de situatie waarin (een der) overlegpartijen concluderen dat het overleg niet zal leiden tot overeenstemming: de 'geschillenregeling', ook wel aangeduid als 'sluitstukregeling', geldend als een sluitstuk op de onderhandelingsfase. ${ }^{25}$ Er werden twee permanente advies- en arbitragecommis-

17 Kamerstukken II 2010/11, 32550, nr. 6, p. 3.

18 F. Dorssemont, The right to bargain collectively, in: N. Bruun e.a., The European Social Charter and Employment Relation, Portland: Hart Publishing 2017, p. 263.

19 Conclusions 2014, Republic of Moldova, Article 6, par. 3 (deferred).

20 Loonstra 1987, p. 48-49. Zie ook voetnoot 6.

21 Besluit van de minister van Binnenlandse Zaken van 20 september 1979 (Stcrt. 1979, 190); voluit Commissie van advies inzake de regeling van voorzieningen bij collectieve arbeidsgeschillen in de openbare dienst.

22 Rapport van de Commissie van advies inzake de regeling van voorzieningen bij collectieve arbeidsgeschillen in de openbare dienst (commissie-Toxopeus II), Den Haag: Staatsuitgeverij 1980.

23 Kamerstukken II 1976/77, 8606, nr. 13, p. 2-3. Na de herziening van het ESH is het voorbehoud bij lid 4 beperkt tot militaire ambtenaren in werkelijke dienst en het burgerlijk Defensiepersoneel (Wet van 1 december 2005, Stb. 694; Kamerstukken II 2004/05, 29941, nr. 3, p. 13).

24 Na het rapport van de commissie-Toxopeus II werd de werkgroep ASIO samengesteld om het overleg over beide voorontwerpen en over het functioneren van het overleg voor te bereiden. Het voorontwerp Wet geschillenoplossing overleg openbare dienst werd in grote lijnen onderschreven door de werkgroep (rapportage van de Werkgroep Aard, Structuur en Inhoud van het Overleg aan het Centraal Georganiseerd Overleg in Ambtenarenzaken, Den Haag, oktober 1980, p. 40).

25 Deze aanduiding werd voor het eerst gebruikt door de commissie-Toxopeus II. De AAC wordt ook aangeduid met de naam van haar voorzitter: aanvankelijk de commissie-Albeda, thans de commissie-Remkes. De LAAC staat thans onder voorzitterschap van Van der Heijden. 
sies in het leven geroepen: de Advies- en arbitragecommissie Rijksdienst voor de sector Rijk, Politie, Defensie en (destijds nog) Onderwijs, ${ }^{26}$ en de Lokale Advies en Arbitragecommissie (LAAC) voor de sector Gemeenten, Provinciën, Waterschappen en gemeenschappelijke regelingen. ${ }^{27}$

\subsection{Procedure}

Zoals de naam al doet vermoeden, heeft de AAC tot taak om op verzoek van de overlegpartijen te adviseren dan wel een bindende arbitrale uitspraak te doen in de voorgelegde collectieve arbeidsgeschillen. Gebruikmaking van de geschillenregeling is niet dwingend voorgeschreven. Tot voor kort vormde artikel 125 lid 1 onder $m$ AW 1929 de wettelijke basis. ${ }^{28}$ De vaste procedure wordt in deze bijdrage evenwel beschreven aan de hand van artikelen 13 tot en met 24 van het Besluit georganiseerd overleg sector Defensie (BGO), aangezien deze sector - als een van de uitzonderingen in de Wnra (artikel 3 onder c AW 2017) - niet is genormaliseerd. Vóór 1 januari 2020 was de procedure voor de sector Rijk op vergelijkbare wijze omschreven in artikelen $110 \mathrm{~b}$ tot en met $110 \mathrm{~h}$ van het Algemeen Rijksambtenarenreglement (ARAR). Voor defensieambtenaren vormen artikel 12 onder $p$ (militairen) en artikel 12o onder $m$ (burgers) Wad de wettelijke basis van de geschillenregeling. Ook voor de sector Defensie is de AAC de aangewezen instantie om geschillen te beslechten. ${ }^{29}$ De commissie bestaat uit vijf leden en vijf plaatsvervangende leden met een bestuurlijke en/of wetenschappelijke achtergrond, die hun sporen hebben verdiend op het terrein van arbeidsverhoudingen. ${ }^{30}$

De procedure wordt als volgt ingeleid. ${ }^{31}$ Indien (een der) partijen de indruk (heeft) hebben dat het overleg niet tot een bevredigende uitkomst zal leiden, dan wordt dit medegedeeld in het overleg, gevolgd door een gelijkluidende schriftelijke mededeling (artikel 15 BGO). Beide partijen kunnen het geschil op deze manier inleiden, dus niet alleen de centrales van overheidspersoneel, maar ook de voorzitter - de minister van Defensie (artikel 7 lid 1 BGO) - zelf. Dit dient ter verzekering van gelijkheid van 'wapens'. ${ }^{32}$ Vervolgens schrijft de voorzitter een overlegvergadering uit om de wijze waarop naar een oplossing van het geschil zal

27 Zie vng.nl/laac over de LAAC. Zie ook L.C.J. Sprengers, Collectieve belangen - uiteenlopende geschillen, in: L.C.J. Sprengers \& A.F.M. Brenninkmeijer, Arbeidsconflicten bij de overheid, Den Haag: CAOP 2003, p. 65-68.

28 Zie ook Kamerstukken II 1993/94, 23792, nr. 3, p. 2.

29 Artikel 18 BGO. Zie voor de sector Politie artikel 23 onder $b$ Besluit overleg en medezeggenschap politie 1994. De Advies- en Arbitragecommissie voor de rechterlijke macht heeft dezelfde samenstelling als de AAC (artikel 39e Besluit rechtspositie rechterlijke ambtenaren).

30 K.M. Becking, De Advies- en Arbitragecommissie Rijksdienst en het belang van de arbeidsvoorwaardenvorming in de collectieve sector, SMA 1992, p. 445-446; K.M. Becking, 'Grand design' Een onderzoek naar processen van normalisering en decentralisering in de arbeidsverhoudingen voor overheidspersoneel in de periode 1990-2000 (diss. Utrecht), Zeist: CAOP 2001, p. 91.

31 De procedure kan worden ingedeeld in vier fasen: kennisgevingsfase, formuleringsfase, advies- of arbitragefase en de voortgezette overlegfase (M.G. Rood, Collectief ambtenarenrecht, Den Haag: VUGA Uitgeverij B.V. 1989, p. 96). 
worden gezocht, te bespreken (artikel 16 lid 2 BGO). Tenzij partijen alsnog het overleg weten voort te zetten zonder tussenkomst van de AAC, hebben zij de keuze uit twee mogelijkheden: (1) zij kunnen aan de AAC advies vragen, of (2) zij kunnen het geschil onderwerpen aan een arbitrale uitspraak. Artikel 16 lid 3 BGO bepaalt dat zowel de voorzitter als de meerderheid van de centrales bevoegd is tot het inwinnen van advies; voor de beslissing om het geschil te onderwerpen aan een (bindende) arbitrale uitspraak is overeenstemming tussen alle deelnemers van het overleg vereist (artikel 16 lid 4 BGO). Een advies heeft geen bindende kracht. Binnen twee weken na ontvangst van het advies moet het overleg over het geschil worden voortgezet (artikel 21) - de zogenoemde 'voortgezette overlegfase'. Indien het voortgezette overleg niet tot overeenstemming leidt, beslist de minister (artikel 24 BGO). Eventueel kunnen partijen het geschil alsnog onderwerpen aan arbitrage. ${ }^{33}$ Een arbitrale uitspraak heeft wel bindende kracht (artikel 22). Zodra de arbitrale uitspraak is gedaan, is het geschil beëindigd.

Voor militairen zijn in het verleden aanvullende geschillenregelingen tot stand gekomen ter compensatie van een (op handen zijnde) wettelijke beperking van het recht op collectieve actie: het ultiem overleg uit 1985 en het sluitstuk op het overleg uit 1993, oftewel de sluitstukregeling. ${ }^{34}$ In 2008 zijn bij invoering van artikel 12i Wad (waarin het stakingsverbod is neergelegd) een protocol met procedures voor het voeren van toegestane vormen van collectieve actie en een procedure met betrekking tot het beslechten van arbeidsconflicten in het vooruitzicht gesteld. ${ }^{35}$ Vooralsnog laat dit protocol op zich wachten. Juist met het oog op essentiële diensten met geen of een beperkt stakingsrecht, is het interessant om op te merken dat de AAC de mogelijkheid heeft tot 'final-offerarbitrage', hoewel dit niet vaak wordt toegepast. ${ }^{36}$ Het zal geen verrassing zijn dat dit voor het eerst werd beproefd in de sector Defensie. ${ }^{37} \mathrm{Bij}$ conventionele arbitrage spreekt de arbiter zich uit over het gehele onderhandelingspakket; de uitspraak kan afwijken van de voorstellen van de partijen. Bij final-offerarbitrage ${ }^{38}$ kiest de arbiter het meest aanvaardbare bod, hetzij het eindbod van werkgeverszijde, hetzij dat van werknemerszijde. Dit kan worden toegepast op het gehele pakket ('total package') of per geschilpunt ('issue by issue'). Als voordeel van final-offerarbitrage wordt genoemd dat het de bereidheid om concessies te doen vergroot, omdat de arbiter kiest voor het eindbod van de partij die het meest redelijk heeft onderhandeld. Bij conventionele arbitrage kan een 'narcotic effect' optreden wanneer partijen inschatten dat

33 Dit heeft gevolgen voor de samenstelling van de AAC: het lid dat betrokken is geweest bij het advies, wordt vervangen door diens plaatsvervanger (artikel 19 lid 2 BGO). Zie ook Besluit van 22 mei 1984, Stb. 1984, 317, p. 10; Besluit van 5 maart 1986, Stb. 1986, 95, p. 10.

34 Zie ook G.L. Coolen, N. Hummel \& G.F. Walgemoed, Hoofdzaken van het militaire ambtenarenrecht, Deventer: Kluwer 2016, par. 87-88; T.H. Dragt, Ten geleide, in: K.M. Becking, H. Dragt, W.S.P. Fortuyn \& C.J. Loonstra (red.), Final-offer arbitrage, Den Haag: Sdu Juridische \& Fiscale Uitgeverij 1993, p. 11.

35 Kamerstukken II 2005/06, 30674, nr. 3, p. 19; Kamerstukken II 2006/07, 30674, nr. 9, p. 1.

36 Final-offer arbitrage werd toegepast in AAC 26 januari 1989, AAC.21 (sector defensie) en AAC 21 december 1995, AAC.47 (sector onderwijs). Zie ook Becking 2001, p. 87.

37 Zie ook Dragt 1993, p. 11.

38 C.J. Loonstra, Final-offer arbitrage als sluitstuk van collectief overleg, in: K.M. Becking e.a. (red.), Final-offer arbitrage, Den Haag: Sdu Juridische \& Fiscale Uitgeverij 1993, p. 32. 
de arbiter de gulden middenweg zal kiezen. ${ }^{39}$ Met name final-offerarbitrage wordt genoemd als waardevolle aanvulling op het collectief actierecht. ${ }^{40}$

\subsection{Praktijk}

\subsubsection{Adviezen/arbitrale uitspraken}

Instelling van de AAC was een eerste maatregel om de disbalans in de verhouding tussen de overlegpartijen bij de overheid recht te trekken. Met name door het formuleren van spelregels, zoals de uitwerking van de norm van open en reëel overleg en het aanbrengen van een scheiding tussen de rollen van de overheid als werkgever en wetgever, wist de AAC enige gelijkwaardigheid tussen de overlegpartijen teweeg te brengen. Nog meer gelijkwaardigheid volgde met de invoering van het overeenstemmingsvereiste (1989) en het sectorenmodel (1993), waarna de AAC de rol aannam als 'een in normale arbeidsverhoudingen functionerend orgaan' ${ }^{41}$ Heeft de AAC daarna nog een rol van betekenis gehad? De beantwoording van deze vraag valt uiteen in een analyse van het aantal adviezen/uitspraken en een verkenning van alternatieve wegen die de overlegpartners plegen te bewandelen bij patstellingen in het overleg. In deze paragraaf staat de kwantitatieve analyse centraal. Vanaf haar instelling in 1984 heeft de AAC in totaal 62 adviezen uitgebracht en 17 arbitrale uitspraken gedaan. ${ }^{42}$ De vraag is of het aantal adviezen/uitspraken mettertijd is afgenomen. Hiertoe is in het kader van deze bijdrage een statistische analyse uitgevoerd. ${ }^{43}$ Deze duidt op een bevestigend antwoord, zoals blijkt uit figuur 1.

Loonstra 1993, p. 13-14; Loonstra 1987, p. 43-47.

Loonstra 1993, p. 15.

Becking 2001, p. 91.

De adviezen/uitspraken van de AAC zijn te raadplegen via www.adviesenarbitragecommissie.nl/ adviezen/.

E.-J. Wagenmakers, Poisson-regression in Labor Law, 9 januari 2020, te raadplegen via bayesianspectacles.org/poisson-regression-in-labor-law/. 


\section{Figuur 1 Behandelde aanvragen van 1984 tot 2020}

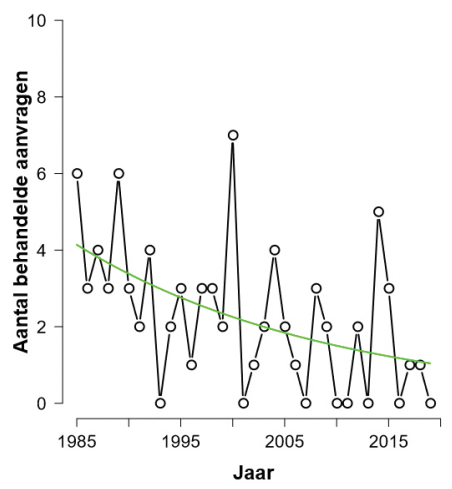

De doorgetrokken dalende lijn komt voort uit de statistische analyse (Poisson regressie). Deze bevestigt het beeld dat het aantal behandelde aanvragen is afgenomen, ondanks enkele uitschieters naar boven, bijvoorbeeld in 2014 en 2015. Uit figuur 1 valt verder op te maken dat deze dalende trend zich vanaf de jaren negentig heeft ingezet. In de literatuur van rond de millenniumwisseling wordt dit onder meer toegeschreven aan de invoering van het overeenstemmingsvereiste in 1989 en de verdere decentralisatie van het arbeidsvoorwaardenoverleg in de sector onderwijs, die tot 2004 hofleverancier van geschillen was bij de AAC. ${ }^{44}$

Figuur 2 beperkt zich tot het aantal behandelde aanvragen vanaf 1990 voor de sectoren Rijk, Politie en Defensie (en bovensectoraal). De horizontale lijn, die in dit geval vrijwel overeenkomt met het gemiddelde aantal aanvragen op jaarbasis, impliceert noch een stijging, noch een daling - oftewel, er is statistische evidentie dat het aantal behandelde aanvragen vanaf 1990 voor deze sectoren gelijk is gebleven.

Kortom, na een overbruggingsperiode van ongelijke naar meer gelijke machtsverhoudingen is de rol van de AAC de afgelopen dertig jaar stabiel gebleven. Op jaarbasis gaat het gemiddeld om 1,5 adviezen/uitspraken ten behoeve van drie sectoren, alsmede sectoroverstijgende zaken. Volgens Van der Heijden kan uit dit geringe aantal zaken worden opgemaakt dat 'arbeidsverhoudingen bij het Rijk,

44 M. Stekelenburg, 200 jaar werken bij de overheid, boek 2, 1940-1998, Den Haag: Sdu 1999, p. 230; Sprengers 2003, p. 62. In verband met de doordecentralisering van de sector onderwijs is het Overlegbesluit Onderwijspersoneel, dat aansluit bij de AAC van artikel 110g ARAR, in 2013 ingetrokken (Besluit van 6 november 2013, Stb. 460). Geschillen in de sector primair onderwijs worden voorgelegd aan de Commissie voor geschillen decentraal georganiseerd overleg (DGO) (Bijlage XIII cao PO ter uitvoering van artikel 38 WPO (oud)). In de cao VO (en in artikel 40a WVO (oud)) ontbreekt een dergelijke regeling. De overlegverplichtingen in de onderwijswetten zijn per 1 januari 2020 komen te vervallen (zie ook Kamerstukken II 2018/19, 35089, nr. 3, p. 5-6). 

en Defensie

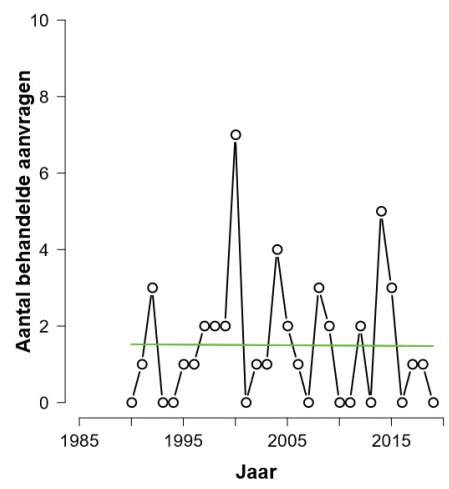

ondanks de tegenstellingen en conflicten, overwegend harmonieus zijn en het overleg veelal in redelijkheid plaatsvindt'. ${ }^{45}$ Sprengers plaatst echter enkele kritische kanttekeningen bij de rol van de AAC. In 2003 vermeldt hij dat de meeste geschillen in de periode van 1998 tot 2002 zagen op 'kleinere, eenduidigere twistpunten'. Hij noemt de AAC daarom vooral een 'beslechter van kleine geschillen' ${ }^{46}$ Deze constatering geldt ook voor het afgelopen decennium: slechts twee van de twaalf behandelde geschillen hadden betrekking op het arbeidsvoorwaardenoverleg. ${ }^{47}$ In vijf zaken was de rol van de AAC zelfs beperkt tot - in de woorden van de commissie zelf ${ }^{48}$ - 'centrale interpretator'. ${ }^{49}$ Over arbeidsvoorwaarden is zelfs nog nooit gearbitreerd. ${ }^{50}$ Toch kan een bestaande infrastructuur om geschillen voor te kunnen leggen van toegevoegde waarde zijn. Sprengers wijst erop dat niet iedere aangelegenheid zwaar genoeg is voor een collectieve actie. Advies van een onafhankelijke commissie kan de partijen verder helpen in het overleg, mede als opening naar de respectieve achterbannen. 'Op het moment dat het cao-overleg is vastgelopen, is het vaak moeilijker om in gezamenlijkheid een geschilbeslechtingsprocedure op te gaan tuigen op ad-hocbasis', voegt Sprengers toe. ${ }^{51}$

J. Koekebakker, Een luisterend oor bij conflicten in het georganiseerd overleg, HR Overheid 2014/8, p. 5.

46 Sprengers 2003, p. 61-64.

47 AAC 16 oktober 2017, AAC.103; AAC 7 februari 2013, AAC.92.

48 AAC 27 januari 1987, AAC.11.

49 AAC 5 september 2018, AAC. 104; AAC 17 november 2015, AAC.102; AAC 29 oktober 2014, AAC.97; AAC 27 mei 2014, AAC.97; AAC 30 november 2012, AAC.91.

50 Zie ook H.A.P.M. Pont, Speech t.g.v. conferentie inzake final-offer arbitrage, in: KM. Becking, Final-offer arbitrage, Den Haag: Sdu Juridische \& Fiscale Uitgeverij 1993, p. 87.

51 L.C.J. Sprengers, Cao-geschillencommissies: doekje voor het bloeden of volwaardige rechtsbescherming?, TAP 2019/61, par. 1.1. Zie ook A.T.J.M. Jacobs, Onderzoek, verzoening, bemiddeling en arbitrage in arbeidsconflicten, in: L. Bots e.a. (red.), Blinde vlekken in het sociaal recht, Deventer: Kluwer 1986, p. 275. 


\subsubsection{Alternatieven}

Opvallend is dat bij de overheid soms toch bemiddeling op ad-hocbasis wordt verkozen boven tussenkomst van de AAC. Wellicht heeft dit te maken met de lange doorlooptijd bij de AAC van vier weken na de advies-/arbitrageaanvraag (artikel 19 lid 3 BGO). In 2015 wist verkenner Hans Borstlap (lid van de Raad van State) de overlegpartijen in de sector Politie bijvoorbeeld nader tot elkaar te brengen na diverse collectieve acties, onder meer tijdens de Tour de France. ${ }^{52}$ In enkele (uitzonderlijke) gevallen heeft de AAC zelf de rol aangenomen van ad-hocbemiddelaar. Officieel is bemiddeling geen taak van de AAC, hoewel bemiddeling en advies in de praktijk in elkaar over kunnen lopen. ${ }^{53}$ Een voorbeeld is de 'lichte adviesaanvraag' in de sector Rijk aan de 'ad hoc Commissie Mobiliteitskaart Rijk', bestaande uit leden van de AAC. ${ }^{54}$ Een ander voorbeeld is de bemiddeling door de $\mathrm{AAC}$ in het geschil bij de Rijksluchtvaartdienst over de salariseisen van de centrales, die verband hielden met een nijpend tekort aan luchtverkeersleiders, waardoor een 'welhaast onwerkbare situatie' was ontstaan. Bij wijze van collectieve actie hadden de luchtverkeersleiders op Schiphol zich massaal ziek gemeld. Tijdens de hoorzitting deed de AAC zelf een voorstel tot bemiddeling. Uit het 'advies' blijkt dat beide partijen zich konden vinden in de door de AAC aangedragen oplossingen. ${ }^{55}$ Wolters acht bemiddeling als afzonderlijke activiteit van de $\mathrm{AAC}$ ongewenst, onder meer omdat de wettelijke rol van de AAC als adviseur/ arbiter ervoor zorgt dat zij door partijen minder snel als bemiddelaar wordt geaccepteerd, en omdat de mogelijkheid om tijdens de bemiddeling alsnog eenzijdig advies te vragen het vrijwillige karakter van de bemiddeling ondergraaft. ${ }^{56}$

Behalve door ad-hocbemiddeling (en collectieve actie) wordt de AAC nog op andere manieren overgeslagen. Soms geven de centrales er de voorkeur aan om het overleg op te schorten, om zodoende de sectorwerkgever onder druk te zetten. ${ }^{57}$ Ook komt het voor dat een 'cao'-conflict voor de rechter wordt uitgevochten. In 2015 bijvoorbeeld, vorderden de centrales in de sector Rijk in een kort geding tevergeefs dat de vrijval van het werkgeversdeel van de pensioenpremie zou worden aangewend als salarisverhoging van $0,8 \% .{ }^{58}$ In dezelfde periode vroegen de centrales de AAC wel om advies over het opnemen van een ouderdomspen-

52 Zie o.a.: Hans Borstlap zoekt oplossing cao-conflict politie, volkskrant.nl 23 september 2015; Onderhandelingen over politie-cao hervat, nrc.nl 2 november 2015; Uitgelekt advies politie-cao: hogere beloning voor agenten, rtlnieuws.nl 9 oktober 2015. Zie ook Hummel, TRA 2016/56.

53 Akkermans 2003, p. 83; Dragt 1993, p. 8.

54 AAC 6 mei 2014, AAC.95.

55 AAC 18 juli 1985, AAC.5.

56 T. Wolters, Onderhandeling en bemiddeling. Een studie op het terrein van de arbeidsverhoudingen (diss. Amsterdam), Amsterdam: VU-uitgeverij 1989, p. 216-217; Becking 1992, p. 449.

57 Zie uitgebreid N. Hummel, Het staken van het overleg als stakingsalternatief, Academie voor Arbeidsrecht 2014, doi:10.5553/ARBAC/.000014.

58 Rb. (vzr.) Den Haag 10 april 2015, ECLI:NL:RBDHA:2015:4045, TAR 2015/7/8, m.nt. N. Hummel en M.J.C.M. van der Poel. Zie ook Rb. Midden-Nederland 21 maart 2014, ECLI:NL:RBMNE: 2014:1100; Rb. Utrecht (pres.) 1 augustus 1991, ECLI:NL:RBUTR:1991:AK5198, TAR 1991/201, welk kort geding ging over de opschortende werking van de procedure bij de AAC en betrekking had op de adviesaanvragen onder nummer AAC.30 en AAC.33 (beide ingetrokken). Zie ook Akkermans 1994, p. 31. 
sioenproduct in de tweede pijler voor deelnemers met een inkomen boven 100.000 euro - een minder belangrijk geschil. ${ }^{59}$ Weliswaar heeft de AAC in de praktijk nog steeds een rol van betekenis, maar de besproken alternatieven wijzen erop dat de commissie en/of de procedure niet geheel tegemoetkomt aan de wensen van de centrales.

\section{De AAC na 1 januari 2020}

\subsection{Van wet naar cao}

Op 1 januari 2020 is de Wnra in werking getreden. Wat betekent dit voor de (procedure bij de) AAC? Bij de viering van het 30-jarig jubileum van de commissie in 2014 werd voorspeld dat ook na normalisering van de rechtspositie van ambtenaren een rol is weggelegd voor de AAC. ${ }^{60}$ Ook in de literatuur is in het verleden gepleit voor behoud van de geschillenregeling. ${ }^{61}$ Desondanks is de wettelijke grondslag voor het maken van afspraken over de beslechting van geschillen in de AW 2017 en de onderwijswetten komen te vervallen. ${ }^{62}$ De regering is van mening dat een dergelijke bepaling niet goed past in een genormaliseerd overlegstelsel: 'In het private arbeidsrecht is het gebruikelijk dat een regeling voor de geschillenbeslechting desgewenst in de cao wordt vastgelegd. Dat is de keuze van de overlegpartners onderling. ${ }^{63}$ Vooralsnog heeft de AAC een rol in het post-Wnra-tijdperk. In de eerste plaats geldt dat voor de AAC wettelijk gezien nog steeds een taak is weggelegd bij Defensie, de Politie en de Rechterlijke macht, in welke sectoren de publiekrechtelijke aanstelling vanwege de uitzondering in artikel 3 AW 2017 wordt gehandhaafd. In de tweede plaats is de AAC 'meegenormaliseerd'. Bijlage 1 van de cao Rijk 2020 leert dat de taak van de AAC in de sector Rijk wordt voortgezet; de procedure zelf is overgeheveld naar bijlage 16 van de cao Rijk 2020. Ook de LAAC keert terug bij lokale overheden. ${ }^{64}$ Sinds de inwerkingtreding van de Wnra is de implementatie van artikel 6 lid 3 ESH in de publieke sector dus voor een (beperkt) aantal sectoren verwezenlijkt bij wet; voor de overige sectoren bij cao.

De keuze om de geschillenregeling bij cao te (laten) verwezenlijken, is niet vanzelfsprekend. Opvallend is dat de regering in de jaren negentig een formeel wettelijke basis juist wel nodig vond, omdat zij meende dat van het advies toch

59 AAC 16 februari 2015, AAC.99.

60 Rede en gezag helpen 'machine weer op stoom', Verslag van de bijeenkomst ter gelegenheid van het 30-jarig bestaan van de Advies- en Arbitragecommissie Rijksdienst, Den Haag 6 november 2014.

61 O.a. L.C.J. Sprengers, De wet op de ondernemingsraden bij de overheid. Op weg naar één arbeidsrecht voor ambtenaren en werknemers? (diss. UvA), 1998, p. 718; Becking 2001, p. 91; A.H.L. de Becker \& K. Deckers, Normalisering van de ambtelijke status: een rechtsvergelijkende kijk op de Nederlandse situatie, TRA 2013/33, par. 6. Anders: Rood 1993, p. 45.

62 Artikel 125 lid 1 onder m AW 1929; artikel 38 Wet op het primair onderwijs; artikel 38 Wet op de expertisecentra; artikel 4.5 lid 5 Wet op het hoger onderwijs en wetenschappelijk onderzoek.

63 Kamerstukken II 2018/19, 35089, nr. 4, p. 3.

64 In de cao Gemeenten 2019-2020 is dit geregeld in bijlage 2; in de cao Provincies in artikel 11.2.4; in de sector waterschappen als niet-bindende modelregeling in artikelen 17-24 van deel 2, Sectorale Arbeidsvoorwaardenregelingen Waterschapspersoneel (Basisregelingen). 
een zekere morele binding uitgaat, hetgeen de bevoegdheid van de overheid als (mede)wetgever beperkt. ${ }^{65}$ Ook de commissie-Toxopeus II, die aan de wieg stond van de geschillenregeling, koos bewust voor een voorziening bij wet vanwege "het belang van de materie'. ${ }^{66}$ Zelf acht ik met name een referentie aan artikel 6 lid 3 ESH en aan ILO-verdrag 151 op zijn plaats. ILO-verdrag 151 ziet specifiek op de vakverenigingsrechten van alle ${ }^{67}$ personen in dienst van de overheid. Artikel 8 van dit verdrag vermeldt 'bemiddeling, verzoening of arbitrage' als mogelijke oplossing van geschillen met betrekking tot de vaststelling van arbeidsvoorwaarden. Uitgangspunt is dat op de overheid de verplichting rust om derdeninterventie op enigerlei wijze te bevorderen teneinde arbeidsconflicten te voorkomen of, indien toch een conflict ontstaat, tot een spoedige oplossing hiervan te komen. ${ }^{68}$ Deze verplichting geldt temeer voor essentiële diensten. ${ }^{69}$ De overheid is hofleverancier van 'essentiële diensten': 'sectors which are essential to the community', ${ }^{70}$ waaronder politie, krijgsmacht, rechterlijke macht, openbaar vervoer, gezondheidszorg en veiligheidsregio's. Bij essentiële diensten zal het belang bij continuïteit van de dienstverlening eerder een beperking van het collectief actierecht rechtvaardigen. ${ }^{71}$ In dat geval is volgens het Committee on the Freedom of Association (CFA) van de ILO compensatie in de vorm van 'adequate, impartial and speedy conciliation and arbitration proceedings' nadrukkelijk geboden. ${ }^{72} \mathrm{Net}$ als de Raad van State in zijn advies gaat de regering hier geheel aan voorbij, terwijl juist artikel 6 lid 3 ESH de directe aanleiding vormde voor de instelling van de AAC. ${ }^{73}$

Het heeft niet mijn voorkeur om de geschillenregeling bij de overheid onderwerp te laten zijn van het cao-overleg, zeker niet waar het gaat om essentiële diensten die door stakingsacties in gevaar kunnen komen. Genormaliseerd of niet, de overheid heeft nog steeds een bijzondere positie als werkgever - én een verantwoorde-

65 Kamerstukken II 1993/94, 23792, nr. 3, p. 2.

66 Commissie-Toxopeus II 1980, p. 9.

67 Zie echter de uitzondering van artikel 1 lid 2 ILO-verdrag 151 ten aanzien van vertrouwensfunctionarissen en hoge beleidsfunctionarissen wier functies in het algemeen van beleidsvormende of managementaard worden beschouwd. Zie ook de uitzondering van artikel 1 lid 3 ten aanzien van de gewapende macht en politie.

68 ILO-aanbeveling 91, artikel I; European Social Charter. Collected (provisional) edition of the 'travaux preparatoires' (volume III), Straatsburg: Raad van Europa 1956, p. 277.

69 Collective bargaining in the public service a way forward. General Survey concerning labour relations and collective bargaining in the public service, Genève: International Labour Office 2013, par. 486. Zie ook Freedom of association. Compilation of decisions of the Committee on Freedom of Association, Genève: International Labour Office 2018, par. 853-863.

70 Conclusies 2010, vol. 1, p. 125 (Azerbeidzjan). Zie ook Conclusies I, 1969/1970, p. 38-39.

71 Zie uitgebreid N. Hummel, Het 'genormaliseerde' collectief actierecht van de politie, TRA 2016/56, par. 3.

72 ILO Compilation 2018, par. 856. Zie ook EHRM 21 mei 2013, 59253/11 (POA e.a./Verenigd Koninkrijk).

73 Aldus ook Sprengers 2019, par. 1.1. Zie ook L.C.J. Sprengers e.a., Op weg naar één arbeidsrecht voor de gehele onderwijssector. Gevolgen van de Wet normalisering rechtspositie ambtenaren (Wnra) voor ambtenaren in het openbaar primair en voortgezet onderwijs en aandachtspunten en aanbevelingen voor cao-partijen, Utrecht: Expertisecentrum Onderwijsgeschillen 2019, p. 37. 
lijkheid jegens de burger, een derde in de zin van artikel G ESH. Daarbij past zo veel mogelijk oplossing van conflicten langs minnelijke weg. ${ }^{74}$ De overheids-cao's van dit moment zijn in beginsel niet meer dan een technische omzetting van de inmiddels vervallen rechtspositiereglementen. Nu het strakke keurslijf van het georganiseerd overleg is afgegooid, althans in wettelijk opzicht, ${ }^{75}$ kunnen deze cao's zich verder gaan ontwikkelen. Wevers en Sick opperen bijvoorbeeld de mogelijkheid dat in de toekomst afscheid wordt genomen van één of meerdere overlegpartners. ${ }^{76}$ In aansluiting hierop is het ook denkbaar dat cao-partijen besluiten om de derdeninterventieclausule te schrappen.

Dit roept de vraag op in hoeverre derdeninterventie bij cao-conflicten is geregeld in de marktsector. Een dergelijke regeling is overigens niet vrijblijvend. Blijkens de conclusies van het ECSR kan instelling van de in artikel 6 lid 3 ESH bedoelde procedure worden verwezenlijkt bij wet, bij cao of door een goed functionerende praktijk. Een van deze manieren volstaat, mits deze voldoende 'doelmatig' blijkt. ${ }^{77}$ Dit laatste moet door de overheid worden gemonitord. ${ }^{78}$ Verder stelt het ECSR twee eisen: ten eerste moet er een procedure zijn, zowel in de publieke als in de private sector; ${ }^{79}$ ten tweede moet blijken dat hier in de praktijk gebruik van wordt gemaakt, hoewel het ECSR hier minder streng mee omgaat in geval van een voorziening bij wet. ${ }^{80}$ In de volgende paragraaf wordt voor de marktsector achtereenvolgens ingegaan op de verwezenlijking bij wet, bij cao en in de praktijk.

\subsection{De norm van de marktsector}

\subsubsection{Verwezenlijking bij wet}

Waarom is derdeninterventie bij cao-conflicten in de marktsector eigenlijk niet wettelijk geregeld? Het arbeidsrecht is niet geheel onbekend met wettelijke oplossingsmechanismen voor collectieve conflicten. Er is bijvoorbeeld een voorziening ter beslechting van medezeggenschapsconflicten, waar Nederland in zijn laatste landenrapport ook aan refereert (zie paragraaf 3.2.2.1), ondanks dat de onder-

Zie ook W. van Voorden, Derden-interventie in arbeidsverhoudingen, SMA 1991, p. 664; Loonstra 1993, p. 31.

75 In hoofdstuk 26 cao Rijk 2020 keert het georganiseerd overleg bijvoorbeeld nog terug.

76 A.M. Wevers \& P.T. Sick, De Wnra en de gebondenheid aan cao's, AR 2020/3, par. 2.

77 Conclusions I, Statement of Interpretation on Article 6, par. 3. Zie ook Conclusions V, Statement of Interpretation on Article 6, par. 3. Zie ook ECSR 21 maart 2018, 116/2015 (Matica Hrvatskih Sindikata/Kroatië), par. 100-108.

78 A. de Roo \& R. Jagtenberg, Europese Mediationpraktijken, Den Haag : Boom Juridische uitgevers 2004, p. 99.

79 Bijvoorbeeld Conclusions 2010, Malta, Article 6, par. 3 (non-conform); Conclusions 2014, Bulgaria, Article 6, par. 3 (non-conform); Conclusions 2014, Azerbaijan, Article 6, par. 3 (nonconform); Conclusions 2014, Armenia, Article 6 par. 3 (non-conform); Conclusions XVII-2, Hungary, Article 6, par. 3 (non-conform).

80 Conclusions XII-2, Malta, Article 6, par. 3 (non-conform). In Conclusions XIII-1, Norway, Article 6 , par. 3 (non-conform) constateerde het ECSR dat gedurende de referentieperiode geen gebruik was gemaakt van de geboden procedure. Omdat het gebruik van deze procedure bij wet is voorzien, achtte het ECSR dit niet in strijd met artikel 6 lid 3 ESH. 
nemingsraad zich nog echt niet heeft ontpopt als 'stakingsleider' ${ }^{81}$ Een geschil over de toepassing van de Wet op de ondernemingsraden (WOR) kan worden voorgelegd aan de bedrijfscommissie (hoofdstuk VII WOR). ${ }^{82}$ Tegenwoordig gaat het hierbij om bemiddeling op vrijwillige basis. ${ }^{83}$ Daarnaast waren er enkele voorzieningen die specifiek zagen op cao-conflicten: de Wet op de Kamers van Arbeid 1897,84 de Arbeidsgeschillenwet 1923 (AGW) ${ }^{85}$ en het wetsontwerp 10110. Deze zijn door Loonstra uitgebreid geanalyseerd in zijn dissertatie Derden-interventie bij cao-conflicten. ${ }^{86}$ In deze paragraaf wordt volstaan met een kort overzicht.

De Wet op de Kamers van Arbeid 1897 voorzag in de oprichting van permanente Kamers van Arbeid, die onder meer tot taak hadden om geschillen over arbeidsaangelegenheden te voorkomen en te vereffenen. In de praktijk hebben deze kamers een geringe rol gespeeld. Loonstra constateert dat ze niet aansloten bij het niveau waarop de arbeidsverhoudingen zich anno 1897 bevonden. 'Overleg tussen de nauwelijks tot wasdom gekomen vakbonden en de ondernemers bestond niet of was nauwelijks aanwezig', aldus Loonstra. ${ }^{87}$ Schlingemann spreekt zelfs van een 'bedroevend resultaat'. Volgens hem kwam dit onder meer doordat de uitspraken niet bindend waren en de voorzitter niet onpartijdig was, waardoor de Kamers van Arbeid onvoldoende vertrouwen genoten bij de in geschil zijnde partijen. ${ }^{88}$ 'Het experiment met de Kamers van Arbeid moge gedurende haar bestaan weinig voordeel hebben afgeworpen, men heeft er nuttige ervaring mede opgedaan voor een verdere staatsinmenging bij arbeidsgeschillen', voegt hij hieraan toe. ${ }^{89}$

In 1923 trad de AGW in de plaats van de Wet op de Kamers van Arbeid. ${ }^{90}$ Doel van deze wet was om 'te voorzien door een stelsel, zoodanig ingericht, dat steeds en overal van overheidswege een orgaan gereed is, hetwelk geacht kan worden het vertrouwen van belanghebbenden te bezitten en bij het ontstaan van conflicten

81 J.J.M. de Laat, De ondernemingsraad als stakingsleider, moeten we echt die kant op?, AR 2019/21, par. 6 en 7; I. Zaal \& J.P.H. Zwemmer, Reactie op: 'De Laat, De ondernemingsraad als stakingsleider, moeten we echt die kant op?', ArbeidsRecht 2019/21, AR 2019/32, par. 4.

82 Zie ook de Geschillencommissie Fusiegedragsregels van de SER, die klachten behandelt bij een fusie (par. 6-8 SER-Fusiegedragsregels 2015). Uit de toelichting bij artikel 19 blijkt dat de geschillencommissie in overleg met partijen ook een bemiddelingspoging kan doen (Besluit van de Sociaal-Economische Raad van 18 september 2015, houdende fusiegedragsregels ter bescherming van de belangen van in de onderneming werkzame personen, Stcrt. 31544, p. 14).

83 L.C.J. Sprengers, Het wetsontwerp aanpassing Wet op de Ondernemingsraden, TRA 2012/96; J.C.M. van Horne, In het voorportaal van de rechter. Een onderzoek naar de bemiddelende en adviserende rol van bedrijfscommissies bij geschillen tussen ondernemer en ondernemingsraad (diss. UvA), Den Haag: Sdu uitgevers 1997, p. 115.

84 Wet van 2 mei 1897, Stb. 141.

85 Wet van 4 mei 1923, Stb. 182.

86 Loonstra 1987, hoofdstuk V, VI en VII.

87 Loonstra 1987, p. 103.

88 G. Schlingemann, Het voorkomen en beslechten van arbeidsgeschillen (diss. Hogeschool Delft), Den Haag: N.V. Boek- en Kunstdrukkerij v/h Mouton \& Co 1933, p. 65-66. Zie ook Loonstra 1987, p. 106.

89 Schlingemann 1933, p. 68.

90 De Wet op de Kamers van Arbeid was reeds ingetrokken bij Wet van 24 november 1922, Stb. 626. 
tot onverwijld handelen in staat is'. ${ }^{91}$ Per district (in totaal vier) werd een permanente Rijksbemiddelaar benoemd, wiens interventie de vorm kon krijgen van tussenkomst, bemiddeling of arbitrage. De Rijksbemiddelaar werd ingeroepen door de burgemeester om, met het oog op de openbare orde, escalatie van het geschil (dus een staking of lock-out) waarbij ten minste vijftig werknemers betrokken waren, te voorkomen. Op verzoek van beide partijen kon de Rijksbemiddelaar een bemiddelingsraad instellen. 'Aangenomen mag toch worden, dat van de werkzaamheid van een bemiddelingsraad, die aan een der partijen wordt opgedrongen, weinig resultaat voor de beslechting van een geschil te verwachten is', aldus de memorie van toelichting. ${ }^{92}$ In de praktijk trad de Rijksbemiddelaar vaak zelf op als bemiddelaar. ${ }^{93}$ Over het algemeen kon het stelsel rekenen op waardering, zowel van werkgevers- als werknemerszijde. ${ }^{94}$ Schlingemann stelt dat in $29 \%$ van het aantal malen dat de Rijksbemiddelaars actief optraden, successen werden geboekt. ${ }^{95}$ Op zich klinkt dit percentage niet erg overtuigend. Ook de cijfers die Josephus Jitta presenteert zijn niet overweldigend. Niettemin spreekt ook hij van 'een zeer bevredigend resultaat', waarbij hij wijst op de moeilijke taak van de Rijksbemiddelaars: 'Ter voorkoming en oplossing van arbeidsconflicten die tot staking of uitsluiting aanleiding geven of dreigen te geven, kunnen door de overheid ingestelde organen slechts een bescheiden deel bijdragen. De voornaamste hulp moet komen van partijen zelf.' ${ }^{96}$

De AGW is na de Tweede Wereldoorlog als gevolg van de geleide loonpolitiek naar de achtergrond verdwenen. ${ }^{97}$ In 1969 is gepoogd om ter vervanging ervan een wet 'met betrekking tot commissies van onderzoek inzake werkstaking' tot stand te brengen. ${ }^{98}$ Dit wetsvoorstel 10110 gold als een 'noodzakelijke aanvulling'99 op wetsvoorstel 10111 betreffende 'wettelijke bepalingen met betrekking tot de werkstaking', waarin de werkstaking werd aanvaard als uiterst middel. ${ }^{100}$ Direct na de bekrachtiging van het ESH is wetsvoorstel 10111 ingetrokken. ${ }^{101}$ Wetsvoorstel 10110 bevatte de verplichting van partijen om de aanzegging van een werkstaking te melden bij de voorzitter van de Sociaal-Economische Raad (SER),

91 L. Leijdesdorff, Arbeidsgeschillenwet 1923, Zwolle: Tjeenk Willink 1923, p. 7.

92 Leijdesdorff 1923, p. 14.

93 A.C.Josephus Jitta, Tien jaren practijk van de Rijksbemiddelaars, Groningen: Wolters 1934, p. 21.

94 Loonstra 1987, p. 149-150.

95 Schlingemann 1933, p. 76. Zie ook Jacobs 1986, p. 277.

96 Josephus Jitta 1934, p. 120. Zie ook M.G. Rood, Naar een stakingswet (diss. Leiden), Deventer: Kluwer 1978, p. 54; Jacobs 1986, p. 276.

97 Gemeend werd dat dit stelsel niet meer paste binnen het kader van de geleide loonpolitiek (Kamerstukken II 1968/69, 10110, nr. 3, p. 3). Met het Buitengewoon Besluit Arbeidsverhoudingen 1945 (Besluit van 5 oktober 1945, Stb. 214) is de AGW feitelijk buiten werking gesteld door de instelling van het College van Rijksbemiddelaars, dat lonen en andere arbeidsvoorwaarden bindend kon vaststellen (artikel 11). Zie ook Jacobs 1986, p. 276.

98 Kamerstukken II 1968/69, 10110, nr. 2. In de bijbehorende memorie van toelichting wordt gerefereerd aan het Advies inzake wettelijke maatregelen inzake staking (1968, nr. 1), Den Haag: Sociaal-Economische Raad 1968 (Kamerstukken II 1968/69, 10111, nr. 3).

99 Kamerstukken II 1970/71, 10110 en 10111, nr. 12, p. 12.

100 Kamerstukken II 1968/69, 10111, nr. 3, p. 4.

101 Kamerstukken II 1979/80, 10111, nr. 5. 
die bij georganiseerde stakingen verplicht was een commissie van onderzoek inzake de werkstaking in te stellen aan de hand van een vooraf opgestelde lijst. Deze commissie had primair tot taak om de achtergronden van een (dreigende) staking vast te stellen, hetgeen eventueel als basis kon dienen voor een minnelijke oplossing van een zodanig conflict (artikel 5). Feitelijk werd een 'versluierde vorm' van verplichte bemiddeling geïntroduceerd, zo valt op te maken uit de memorie van toelichting: 'Het dient geheel ter beoordeling van een commissie van onderzoek te staan of zij het opportuun acht in enig stadium van het overleg of eventueel na het afbreken van het overleg verdere initiatieven tot verzoening van partijen, bijvoorbeeld door het doen van enig bemiddelingsvoorstel, te ontplooien.' ${ }^{102} \mathrm{Na}$ negatief advies van de Stichting van de Arbeid in 1985 is het wetsvoorstel ingetrokken. ${ }^{103}$ De Stichting van de Arbeid meende dat 'de voorziening als voorgesteld in dit wetsontwerp, het door het Bestuur gekozen uitgangspunt dat partijen bij een conflict in volledige vrijheid moeten kunnen beslissen of zij van bemiddeling en/of arbitrage gebruik wensen te maken, te veel wordt bedreigd'. ${ }^{104}$ Jacobs wijst hierbij op de vrees aan werknemerszijde dat het wetsvoorstel zou leiden tot beperkingen van het stakingsrecht. ${ }^{105}$ Tot een jaar of tien geleden hield de Stichting van de Arbeid zelf een lijst bij van vertrouwenspersonen aan wie, indien alle bij een conflict betrokken partijen dat wensen, om bemiddeling kan worden verzocht. ${ }^{106}$ Hiervan is weinig gebruik gemaakt. ${ }^{107}$

$\mathrm{Na}$ intrekking van wetsvoorstel 10110 pleitte Jacobs voor een reactivering van de AGW ter voorkoming van collectieve acties en daarmee gepaard gaande economische schade. ${ }^{108}$ Loonstra bracht hier tegenin dat de AGW een inbreuk maakte op de voorwaarde van vrijwilligheid en cao-partijen bovendien een te beperkt scala van vormen van derdeninterventie bood. Aangenomen dat derdeninterventie alleen effectief kan zijn als de vorm aansluit op het onderhandelingsgedrag dat voorafgaat aan het conflict, betekende dit volgens hem dat de wet niet vooraf grenzen moet stellen aan 'het beschikbare interventie-potentieel'; alleen de caopartijen zelf zijn 'bij machte de meest geëigende vorm van interventie vast te stellen'. ${ }^{109}$ Niettemin concludeerde Loonstra dat een voorziening bij wet, gezien de wijze waarop het cao-overleg plaatsvindt, levensvatbaar is, mits voldaan wordt aan een aantal voorwaarden. ${ }^{110}$ Sindsdien is het onderwerp naar de achtergrond

102 Kamerstukken II 1968/69, 10111, nr. 3, p. 5; Loonstra 1987, p. 177.

103 Kamerstukken II 1985/86, 10110, nr. 14; Kamerstukken II 1985/86, 10110, nr. 15.

104 Advies inzake een aantal aspecten van de stakingsproblematiek, Den Haag: Stichting van de Arbeid 12 juni 1985, zoals geciteerd door R.A.A. Duk, Het advies van de Stichting van de Arbeid: 'inzake een aantal aspecten van de stakingsproblematiek': agreeing to disagree, en hoe nu verder?', SMA 1985/9, p. 568.

105 Jacobs 1986, p. 273.

106 Jacobs 2017, par. 8.17; Rood 1993, p. 45. Zie ook Kamerstukken II 1985/86, 10110, nr. 15; Duk 1985, p. 568.

107 Akkermans 1994, p. 81.

108 Jacobs 1986, p. 275-282.

109 C.J. Loonstra, Terugkeer naar de Arbeidsgeschillenwet?, SMA 1988, p. 843-844. Zie ook Loonstra 1987, p 134-141. Zie ook W. van Voorden, Derden-interventie in arbeidsverhoudingen, SMA 1991, p. 658-664.

110 Loonstra 1987, p. 186. 
verdwenen en heeft de discussie zich toegespitst op de ultimum remedium-toets (zie paragraaf 4.1). ${ }^{111}$ Slechts zelden wordt in de literatuur nog gezinspeeld op een wettelijke regeling van derdeninterventie bij cao-conflicten. ${ }^{112}$

\subsubsection{Verwezenlijking bij cao}

\subsubsection{Landenrapporten}

Cao-partijen zijn vrij om bepalingen op te nemen omtrent het vastlopen van de onderhandelingen na afloop van de betreffende cao. De vraag is hoe vaak dergelijke obligatoire ${ }^{113}$ bepalingen voorkomen. Een eerste aanknopingspunt bieden de landenrapporten van Nederland in het kader van het toezicht op artikel 6 lid 3 ESH. Bij de ratificatie van het ESH ging de aandacht in Nederland vooral uit naar het collectief actierecht van artikel 6 lid 4 ESH en de overheidssector. Wat betreft de marktsector wees de wetgever er destijds op dat het sociale beleid in Nederland is gericht op het vreedzaam oplossen van arbeidsgeschillen én dat veel cao's bepalingen bevatten betreffende de oplossing van arbeidsgeschillen. ${ }^{114}$ Tot nu toe heeft Nederland op dit punt steeds kunnen rekenen op conform-conclusies. ${ }^{115}$ In het landenrapport van 2013 schetst Nederland het volgende beeld: ${ }^{116}$

'As a rule, collective agreements in the Netherlands contain provisions on dispute resolution. If an employer and one or more employees interpret any part of a collective agreement differently, the matter may be put before a committee comprising employers' and trade union representatives, usually chaired by an independent party.'

Bepalingen over alternatieve geschillenbeslechting inzake de uitleg, toepassing of uitvoering van de cao komen inderdaad veelvuldig voor in cao's. ${ }^{117}$ Dit wordt ook wel 'bedrijfsrechtspraak' genoemd. Voorbeeld is de geschillencommissie van ABN

111 Zie ook voetnoot 149 .

112 Jacobs 2017, par. 7.10; J. Heinsius, Collectief ontslagrecht: enkele voorstellen betreffende een betere regelgeving (diss. Leiden), Den Haag: Boom Juridische uitgevers 2004, p. 395; Akkermans 2003, p. 90-92; Sprengers 1998, p. 129-30. Anders: Van Voorden 1991, p. 663-664.

113 De bepalingen die de relaties tussen cao-partijen onderling regelen, komen naar hun aard niet in aanmerking voor algemeenverbindendverklaring (Toetsingskader algemeen verbindendverklaring cao-bepalingen, par. 4.3).

114 Kamerstukken II 1965/66, 8606 (R533), nr. 3, p. 5. In 1922 was 90\% van het aantal arbeiders dat onder een cao viel gebonden aan een eigen geschillenregeling; in 1940 73\% (C.J.H. Jansen \& C.J. Loonstra, De inhoud van collectieve arbeidsovereenkomsten in het interbellum, SMA 1994, p. 159 en 160).

115 Dit geldt afgezien van de beginjaren waarin nog geen oordeel kon worden gegeven (Conclusions VIII, Netherlands, Article 6, par. 3).

116 7th National Report on the implementation of the European Social Charter, Netherlands 2013, p. 28.

117 Boot stelt in 2018 dat een dergelijke bepaling in ongeveer de helft van de onderzochte cao's voorkomt (G.C. Boot, Arbitrageclausules in arbeidsovereenkomsten, TvA 2018/69). Zie ook Sprengers 2019. 
AMRO. ${ }^{118}$ Gevolg van dergelijke arbitrage of bindend-adviesclausules in de cao is dat de werknemer geen of slechts een beperkt beroep kan doen op de rechter. ${ }^{119}$ Echter, het gaat hierbij om de beslechting van individuele arbeidsgeschillen. Artikel 6 lid 3 ESH strekt juist tot het waarborgen van de doeltreffende uitoefening van het recht op collectief onderhandelen, waarbij het dus gaat om belangengeschillen. Hieronder verstaat het ECSR conflicten die betrekking hebben op het sluiten van een cao of wijziging van arbeidsvoorwaarden in het kader van collectieve onderhandelingen. Het gaat dus niet om rechtsconflicten (conflicten over de uitleg en toepassing van de cao). ${ }^{120}$ Desondanks bleek het ECSR tevreden gesteld. ${ }^{121}$ Dat de landenrapporten van Nederland hierover zwijgen (en in plaats daarvan een onjuiste voorstelling van zaken geven), doet vermoeden dat verwezenlijking bij cao (of op andere wijze) niet gebruikelijk is. Kennelijk ervaren de sociale partners dit ook niet als een probleem: het laatste landenrapport gaat vergezeld van uitgebreide kritiek van de FNV op de ruimhartige wijze waarop de rechter artikel G ESH uitlegt bij de beoordeling van de rechtmatigheid van een collectieve actie, terwijl artikel 6 lid 3 ESH niet wordt genoemd. ${ }^{122}$

\subsubsection{Cao-onderzoek}

Om te beoordelen of het gebruikelijk is dat cao's bepalingen bevatten inzake bemiddeling of arbitrage bij collectieve geschillen heb ik 88 cao's onderzocht. Deze steekproef sluit aan bij die van de rapportage 'Cao-afspraken 2018' van het ministerie van Sociale Zaken en Werkgelegenheid (SZW), met dien verstande dat de ambtenaarrechtelijke 'cao's' en de onderwijs-cao's buiten beschouwing zijn gelaten, omdat in deze sectoren een wettelijke voorziening geldt/gold. ${ }^{123}$ Slechts vier cao's bevatten een bepaling over derdeninterventie bij geschillen tussen de cao-partijen over wijziging of vernieuwing van de cao - een teleurstellende oogst. Van twee daarvan is de reikwijdte beperkt tot tussentijdse wijzigingen bij buitengewone omstandigheden (een zogenoemde 'openbreekclausule'). ${ }^{124}$ De resterende

118 Artikel 1.3 en bijlage IV cao ABN AMRO 1 januari 2018 - 1 januari 2020. Zie ook A.H. van Empel \& R. Hansma, Praktijkervaring met een cao-commissie, ArA 2015/01.

119 G.W. van der Voet, Alternatieve geschillenprocedures in cao's, TC 2009/4, p. 23. G.C. Boot, Arbitrageclausules in arbeidsovereenkomsten, TvA 2018/69.

120 Conclusions 2010, Georgia, Article 6, par. 3 (non-conform).

121 Conclusions 2014, Netherlands, Article 6, par. 3 (conform). Zie ook Conclusions 2018, Netherlands, Article 6, par. 3 (conform).

122 Comments by FNV on the 11th National Report on the implementation of the European Social Charter, Netherlands: 2018.

123 Bijlage bij Kamerstukken II 2018/19, 29544, nr. 919 (Cao-afspraken 2018). Uit bijlage IX blijkt dat de 99 steekproef-cao's van toepassing zijn op bijna 4,8 miljoen werknemers (85\% van alle werknemers onder een cao). De steekproef bestaat uit 66 bedrijfstak-cao's, van toepassing op 95\% van de werknemers, en 33 ondernemings-cao's, van toepassing op 5\% van de werknemers onder de steekproef. Op 1 januari 2019 waren er in totaal 454 lopende cao's (141 bedrijfstakcao's en 313 ondernemings-cao's). Het eigen onderzoek, dat is afgesloten op 20 december 2019, betreft de meest actuele versie van de steekproef-cao's.

124 Artikel 4 cao Landwerktuigen Exploiterende Ondernemingen 1 juli 2017 - 30 juni 2019 ('tussentijdse wijzigingen'); artikel 74 cao Hoveniersbedrijf 1 juli 2018 - 30 juni 2020 ('tussentijdse wijzigingen'). Zie ook J. van Drongelen \& P.A.L. de Jong, Vredesplicht- en openbreekclausules in collectieve arbeidsovereenkomsten, Zutphen: Uitgeverij Paris 2014, p. 60-61. 
twee cao's gelden beide in de metaal- en elektrotechnische industrie (Metalelektro), die gebruikmaakt van model cao-bepalingen. ${ }^{125}$ In deze bedrijfstak is de Bemiddelingsinstantie voor de Metalelektro aangewezen om op verzoek van één of meer vakbonden en/of de werkgeversorganisatie te bemiddelen bij voorgenomen acties. ${ }^{126}$ Op basis van het cao-onderzoek kan worden geconcludeerd dat de arbitrage-/adviesclausules in de nieuwe overheids-cao's een vreemde eend in de bijt zijn. ${ }^{127}$

\subsubsection{Jurisprudentie}

Uit de gepubliceerde jurisprudentie blijkt verder nog dat meerdere cao's in de luchtvaartsector, die niet wordt meegenomen in de steekproef van het ministerie van SZW, een bemiddelingsclausule bevatten. In artikel 13.3 van de cao KLM Grondpersoneel bijvoorbeeld, spreken partijen een intentie uit tot derdeninterventie: 'Mocht overeenstemming niet kunnen worden bereikt, dan zullen bemiddeling en/of arbitrage in beginsel de voorkeur hebben.' Meerdere cao's in de luchtvaartsector bevatten een met artikel 13.3 vergelijkbare bepaling (zie paragraaf 4.3.1). Dat de afgelopen jaren regelmatig actie wordt gevoerd op Schiphol, doet vermoeden dat dit in de vergetelheid is geraakt. ${ }^{128}$ Toch werd in 2018 een staking van KLM-piloten voorkomen door een onafhankelijke bemiddelaar. Dit was op voorstel van de Vereniging Nederlandse Verkeersvliegers (VNV), die daarmee een duidelijk signaal af wilde geven 'dat iedere poging wordt ondernomen om stakingen te voorkomen'. ${ }^{129}$ KLM refereerde aan de bemiddelings- en arbitrageclausule in de cao KLM Vliegers, en zag de instelling van een bemiddelaar 'als een logische en gewenste vervolgstap en als een ultieme kans om alsnog tot overeenstemming te komen'. ${ }^{130}$

Ondanks dit succesverhaal is het algemene beeld dat bemiddelings- en arbitrageclausules in cao's buiten de luchtvaartsector schaars zijn. De vraag is hoe dit kan worden verklaard. Loonstra duidt de situatie dat cao-partijen zich vooraf, dus vóórdat het geschil escaleert, verbinden om hun geschillen op te lossen via derdeninterventie aan als 'pseudo-vrijwillige derden-interventie'. Uit literatuuronderzoek maakt hij op dat een dergelijke verplichting niet bevorderend is voor het onderhandelingsproces, niet alleen bij (conventionele) arbitrage, maar ook bij bemiddeling. Indien partijen vooraf weten dat een bemiddelaar wordt ingescha-

125 Van Drongelen \& De Jong 2014, p. 46.

126 Artikel 7.9 cao Metalelektro basis 1 juni 2018 - 30 november 2020; artikel 7.7 cao Metalelektro HP 1 juni 2018 - 30 november 2020. Zie ook Van Drongelen \& De Jong 2014, p. 46-48.

127 Op basis van de steekproef van 88 cao's kan met 95\% zekerheid worden gesteld dat het aantal cao's (van de overgebleven 366) dat een bemiddelings-/arbitrageclausule heeft, ligt tussen 2 en 31. De modus (meest waarschijnlijke waarde) is $2,3 \%$ (2 uit 88 ).

128 O.a.: Grondpersoneel KLM op Schiphol staakt woensdagmorgen opnieuw, nrc.nl 2 september 2019; Nieuwe stakingen grondpersoneel KLM aangekondigd, nrc.nl 14 september 2019; Deel KLM-vluchten vertraagd door stakingen cabinepersoneel, nos.nl 15 september 2017. Zie ook Rb. Noord-Holland 16 oktober 2019, ECLI:NL:RBNHO:2019:8589 over de acties van de cateringmedewerkers, die vallen onder de cao voor de contractcateringbranche.

129 Piloten willen ultieme poging doen KLM voor cao te overtuigen, vnv.nl 21 augustus 2018.

130 Reuling Schutte als bemiddelaar tussen KLM \& VNV, klm.nl 24 augustus 2014. Zie artikel 13.3 cao voor KLM-vliegers op vleugelvliegtuigen. 
keld bij het vastlopen van de onderhandelingen, zal er niet echt worden onderhandeld. Daarom werkt pseudo-vrijwillige bemiddeling volgens hem niet bevorderend voor de concessiebereidheid. ${ }^{131}$ In dit licht acht ik het begrijpelijk dat bemiddelings- en/of arbitrageclausules zelden voorkomen.

Praktisch punt is nog dat obligatoire cao-bepalingen in beginsel geen nawerking hebben, tenzij partijen dit zelf afspreken. ${ }^{132}$ Dit kwam naar voren in het kort geding ter voorkoming van een staking van het grondpersoneel van KLM op 3 augustus 2016. Hierin ontleende KLM aan artikel 13.3 het argument dat deze actie prematuur was; de FNV had eerst bemiddeling via een externe derde moeten proberen. ${ }^{133}$ FNV bracht hier onder meer tegenin dat inmiddels geen cao meer bestond, waardoor KLM ten onrechte een beroep deed op artikel 13.3. ${ }^{134}$ De voorzieningenrechter liet dit verder in het midden en toetste aan artikel 6 lid 4 ESH (zie paragraaf 4.3.1). Om discussie te voorkomen bij uitloop van de cao-onderhandelingen is het in ieder geval raadzaam om de geschillenclausule dusdanig te formuleren dat duidelijk is dat deze ook geldt in een cao-loos tijdperk, althans indien cao-partijen dit wenselijk achten. ${ }^{135}$

\subsubsection{Verwezenlijking in de praktijk}

Als in de marktsector al wordt gekozen voor bemiddeling, dan vindt dit, gelet op het voorgaande, doorgaans plaats op ad-hocbasis. ${ }^{136}$ Dat Nederland ook hier niets over vermeld in het landenrapport, lijkt mij een aanwijzing dat dit niet vaak voorkomt. De literatuur bevestigt dit beeld: 'De neiging bij cao-partijen in de marktsector [is] niet groot om derden te betrekken bij patstellingen in het collectief overleg met uitzondering van de kort gedingrechter bij geschillen over de geoorloofdheid van een collectieve actie', stelt Sprengers. ${ }^{137}$ Naar aanleiding van de succesvolle derdeninterventie in het cao-conflict in de schoonmaaksector in 2010 werpt Strating de vraag op waarom cao-partijen niet vaker een derde inschakelen om hun meningsverschil op te lossen en stakingen te voorkomen. 'Dat kan te maken hebben met angst om de regie aan een derde partij uit handen te geven, met weerzin tegen de publiciteit die vaak met bemiddeling gepaard gaat of zelfs

131 Loonstra 1987, p. 39-40. Vergelijk Rood 1978, 117-118.

132 W.J.P.M. Fase \& J. van Drongelen, CAO-recht, Deventer: Kluwer 2004, p. 106-107; Jacobs 2017, par. 5.4.4; Rb. Haarlem 11 mei 2012, ECLI:NL:RBHAA:2012:BW5550, JAR 2012/166. Zie ook Rb. Midden-Nederland 13 maart 2015, ECLI:NL:RBMNE:2015:1701, JAR 2015/103, m.nt. E. Kootvan der Putte; Hof Arnhem-Leeuwarden 8 december 2015, ECLI:NL:GHARL:2015:9269; JAR 2016/12 , m.nt. E. Koot-van der Putte, TRA 2016/37, m.nt. M.S.A. Vegter (VOBN/FNV).

133 Rb. Noord-Holland 11 augustus 2016, ECLI:NL:RBNHO:2016:6696, JAR 2016/208, m.nt. A. Stege, r.o. 4.7. Zie ook Hof Amsterdam 26 augustus 2016, ECLI:NL:GHAMS:2016:3472, TRA 2016/95, m.nt. J.J.M. de Laat, JIN 2016/186, m.nt. A.M.W. van Vlodrop, JAR 2016/229, m.nt. A. Stege.

134 Rb. Noord-Holland 11 augustus 2016, ECLI:NL:RBNHO:2016:6696, r.o. 4.7.

135 Obligatoire bepalingen kunnen worden uitgelegd aan de hand van de Haviltex-norm zoals geformuleerd in HR 13 maart 1981, ECLI:NL:HR:1981:AG4158, NJ 1981, 635, m.nt. C.J.H. Brunner (S.F. Sagel, DSM/Fox en de uitleg van arbeidsrechtelijke contracten - het laatste woord?, ArA 2004/3, p. 84).

136 Sprengers 2005, par. 7.1; Sprengers 2019, par. 1.1; Jacobs 2017, par. 8.16.

137 Sprengers 2005, par. 7.1. Zie ook Sprengers 2019, par. 1.1. 
met de intrinsieke waarde die vakbonden soms aan het voeren van collectieve acties toekennen', aldus Strating. ${ }^{138}$

Uit de mediaberichten erover kan worden opgemaakt dat ad-hocbemiddeling niet helemaal een exoot is bij collectieve arbeidsconflicten. Onlangs nog viel te lezen dat bemiddelaars zijn aangesteld om de vastgelopen onderhandelingen in het basisonderwijs en de zorg - weliswaar nadat actie was gevoerd - vlot te trekken. ${ }^{139}$ Een ander voorbeeld is het conflict tussen Vroom \& Dreesman en de bonden in het voorjaar van 2015 over het zogenoemde 'loonoffer': een eenzijdige loonsverlaging van bijna $6 \%$, ingegeven door de verslechterende bedrijfseconomische situatie van de retailer. De bonden spanden een kort geding aan, waarin de kantonrechter oordeelde dat de loonsverlaging niet terecht was. ${ }^{140} \mathrm{~V} \& \mathrm{D}$ ging in hoger beroep, maar het gerechtshof Amsterdam drong aan op bemiddeling. Het vinden van een geschikte bemiddelaar duurde enkele weken, omdat de door het gerechtshof gesuggereerde kandidaat aanvankelijk niet beschikbaar was. ${ }^{141}$ Uiteindelijk wist deze de vastgelopen onderhandelingen uit het slop te trekken en een kleine maand later werd een akkoord bereikt. ${ }^{142}$

Ondanks de goede uitkomst onderstreept dit voorbeeld het nut van een permanente voorziening tot welke partijen zich vrijwillig kunnen wenden. Het zoeken van een geschikte en beschikbare ad-hocbemiddelaar kan enige tijd in beslag nemen en de te maken afspraken hierover kunnen zelf weer onderwerp van conflict worden. ${ }^{143}$ Bijkomend voordeel is dat een permanent bemiddelingscollege sectorspecifieke deskundigheid - en daarmee vertrouwen - kan opbouwen. Daar kan tegenin gebracht worden dat, indien geïnstitutionaliseerde bemiddeling om wat voor reden dan ook minder goed functioneert, cao-partijen ermee opgescheept zitten. 'Bij organen ad hoc komt een dergelijk bezwaar hoogstens éénmaal voor', stelt Schlingemann enigszins schertsend. ${ }^{144}$ Voordeel van ad-hocbemiddeling vindt hij juist dat partijen zelf voor personen kunnen kiezen die bekend zijn met de toestanden in de bedrijfstak, en/of daar 'personae gratae' zijn. ${ }^{145}$ De vrijheid die dit partijen laat, past op zich bij het Nederlandse stelsel van caoonderhandelingen, waarin grote waarde wordt gehecht aan de autonomie van de cao-partijen. Een voorzichtige conclusie is dat ad-hocbemiddeling slechts incidenteel voorkomt. Vermoedelijk is geen sprake van een goed functionerende praktijk in de in van artikel 6 lid 3 ESH, hoewel alleen nader empirisch onderzoek dit daadwerkelijk kan uitwijzen.

138 H. Strating, Voorkom escalatie van cao-conflicten, Tijdschrift Conflicthantering 2010/ 8, p. 40-44. Zie ook Jacobs 2018, par. 7.1.

139 Verkenner aangesteld om conflict over ziekenhuis-cao vlot te trekken, nos.nl 21 november 2019; SER-voorzitter Hamer aangesteld als bemiddelaar cao basisonderwijs, nrc.nl 26 november 2019.

140 Rb. Amsterdam 23 februari 2015, ECLI:NL:RBAMS:2015:899, AR-Updates.nl 2015-0183, m.nt. R.M. Beltzer.

141 Peter Ingelse treedt aan als bemiddelaar in loonconflict V\&D, fd.nl 12 juni 2015.

142 Geen loonsverlaging bij V\&D - wel 400 ontslagen, nrc.nl 3 juli 2015.

143 Jacobs 1986, p. 274-275; De Roo \& Jagtenberg 2005, p. 3.

144 Schlingeman 1933, p. 59.

145 Schlingeman 1933, p. 59. Zie ook Loonstra 1987, p. 180. 
Het voorgaande leidt tot de conclusie dat de advies-/arbitrageclausules in de nieuwe overheids-cao's niet aansluiten bij de praktijk in de marktsector. Wat gebeurt er indien de overheids-cao's 'trendvolger' worden? Wordt dan ook bij de overheid volstaan met ad-hocbemiddeling? Mijns inziens verhoudt dit scenario zich nóg slechter met de bijzondere positie van de overheid als werkgever. Een ander argument tegen een voorziening bij cao komt uit onverwachte hoek. Een van de redenen dat er in de marktsector geen wettelijke voorziening (meer) is, is kennelijk de vrees dat deze afbreuk doet aan het collectief actierecht (zie paragraaf 3.2.1). In de volgende paragraaf zal blijken dat ook een voorziening in de cao beperkend kan werken.

\section{$4 \quad$ Invloed op het collectief actierecht}

\subsection{Ultimum remedium}

Uit de opbouw van artikel 6 ESH - overleg (lid 1), onderhandelen (lid 2), bemiddeling (lid 3), collectieve actie (lid 4) - wordt wel opgemaakt dat de collectieve actie geldt als uiterst middel. ${ }^{146}$ De invulling die de Nederlandse rechter tot voor kort gaf aan het samenstel van artikel 6 lid 4 ESH en artikel G ESH bestond uit een spelregeltoets, met als spelregels (ofwel zwaarwegende procedureregels) het inzetten van de staking als ultimum remedium en het tijdig aanzeggen van de actie, gevolgd door een proportionaliteitstoets. Met name de ultimum remedium-toets heeft het moeten ontgelden bij het ECSR, dat meent dat dit leidt tot 'an impingement on the very substance of the right to strike as this allows the judge to exercise one of the trade unions' key prerogatives, that of deciding whether and when a strike is necessary'. ${ }^{147}$ In de literatuur werd eveneens stevige kritiek geleverd op deze spelregel. ${ }^{148}$ In het Amsta-arrest van juni 2015 maakte de Hoge Raad duidelijk dat de spelregels niet langer een zelfstandige maatstaf zijn om te beoordelen of een collectieve actie rechtmatig is. In plaats daarvan dienen zij als gezichtspunt te worden betrokken bij de proportionaliteitstoets: een materiële toets op grond van artikel G ESH of op grond van een afweging van alle omstandigheden in redelijkheid tot de collectieve actie kan worden gekomen. ${ }^{149}$ Sinds-

146 HR 28 januari 2000, ECLI:NL:HR:2000:AA4618, r.o. 3.3 (Douwe Egberts).

147 Conclusions XVII-1, Netherlands, Article 6, par.4.

148 Bijvoorbeeld A.P.C.M. Jaspers, Nederlands stakingsrecht op een nieuw spoor?, Deventer: Kluwer 2004; F. Dorssemont, De prullenbak, een locus naturalis voor het leerstuk van misbruik van stakingsrecht, SR 2002/11, p. 320-331. Zie voor een overzicht van de kritiek van het ECSR en in de literatuur o.a. conclusie A-G J. Spier bij HR 19 juni 2015, ECLI:NL:HR:2015:1687, r.o. 4.7-4.12; A.W. Haverkort \& I. Witte, Ontwikkeling van het stakingsrecht na kritiek van het ECSR, TAP 2013/3, p. 114-118; I. van der Helm, Procedureregels in het stakingsrecht: van spelregeltoetsing naar gezichtspunten, AR 2016/5; M. Diepenbach, Stakingsrecht en spelregeltoets: Hoge Raad bekent kleur in zijn arrest van 19 juni 2015, ECLI:NL:HR:2015:1687 (Abvakabo FNV/Stichting Amsta), TvAO 2015/3, p. 111.

149 HR 19 juni 2015, ECLI:NL:HR:2015:1687, r.o. 3.3 (Abvakabo FNV/Stichting Amsta). Zie ook HR 31 oktober 2014, ECLI:NL:HR:2014:3077 (FNV c.s./Enerco). 
dien heeft de ultimum remedium-toets in Nederland nog slechts in enkele gevallen een rol gespeeld bij een beperking of verbod van een collectieve actie. ${ }^{150}$

De vraag is hoe het ultimum remedium-gezichtspunt zich verhoudt tot artikel 6 lid 3 ESH. Het ECSR biedt slechts beperkt ruimte voor het opleggen van procedureregels, voorafgaande aan een collectieve actie. In de eerste plaats valt hierbij te denken aan de vredesplicht, waarbij de cao wordt beschouwd als een 'peace treaty'. In paragraaf 4.3.2 kom ik hierop terug. Verder acht het ECSR het inlassen van een afkoelingsperiode van een redelijke duur bij een dreigende collectieve actie niet in strijd met artikel 6 lid 4 ESH: '[S]uch provisions do not impose a real restriction on the right to collective action, they simply regulate the exercise thereof. ${ }^{\text {'151 }}$ Het ECSR relateert de afkoelingsperiode aan derdeninterventie: 'Periods of notice or cooling-off periods prescribed in connection with pre-strike conciliation procedures are in conformity with Article $6 \S 4$ as long as they are of a reasonable duration.' ${ }^{152}$ Zelfs verplichte bemiddeling is, gelet op artikel 6 lid $3 \mathrm{ESH}$, toegestaan 'as long as it is not so slow that the deterrent effect of a strike is affected'. ${ }^{153}$ Een bemiddelingstermijn van dertig dagen werd bijvoorbeeld 'excessive' geacht. ${ }^{154}$ Dorssemont plaatst hier terecht vraagtekens bij. Volgens hem moet verplichte bemiddeling de toets van artikel G ESH doorstaan, omdat dit nu eenmaal een aantasting vormt van het recht op vrije onderhandelingen. ${ }^{155}$

Het ESH heeft een sterke link met de ILO-verdragen. In het travaux preparatoires wordt artikel 6 lid 3 ESH bijvoorbeeld vergeleken met de aanbeveling van 1951 (nr. 92) inzake vrijwillige bemiddeling en arbitrage. ${ }^{156}$ Het ECSR verwijst in zijn conclusies ook regelmatig naar de ILO-toezichthouders. ${ }^{157}$ Het Comité voor de vakverenigingsvrijheid (CFA) van de ILO lijkt nagenoeg dezelfde koers te varen als het ECSR. In het algemeen acht het CFA het opleggen van een afkoelingsperiode van een redelijke duur ('as to allow the parties to seek a negotiated solution through mediation or conciliation efforts') niet in strijd met de vakverenigingsvrijheid. ${ }^{158} \mathrm{Bij}$ een voorgenomen staking van essentiële diensten

150 Rb. Den Haag 13 december 2018, ECLI:NL:RBDHA:2018:15444, r.o. 4.3.3; Rb. Noord-Holland 16 oktober 2019, ECLI:NL:RBNHO:2019:8589, r.o. 4.15.

151 Conclusions I, Statement of interpretation on Article 6, par. 4; Conclusions XIV-1, Cyprus, Article 6 , par. 4.

152 Conclusions XIV-1, Cyprus, Article 6, par. 4; ESH Digest 2018, p. 106.

153 Conclusions 2006, Albania, Article 6, par. 4. Zie ook Digest of the case law of the European Committee of Social Rights, Straatsburg: Raad van Europa 2018, p. 106.

154 Conclusions XVII-1, Czech Republic, Article 6, par. 4 (non-conform). Uit Conclusions XXI-3, Czech Republic, Article 6, par. 4 (non-conform) blijkt dat deze periode later is bijgesteld naar twintig dagen, volgens het ECSR 'an improvement in the situation'.

155 Dorssemont 2017, p. 263.

156 European Social Charter. Collected (provisional) edition of the 'travaux preparatoires' (volume III), Straatsburg: Raad van Europa 1956, p. 388.

157 Bijvoorbeeld Conclusions XIV-1, Iceland, Article 6, par. 3 (non-conform); Conclusions XIV-1, Iceland, Article 6, par. 2 (conform), in welke conclusies wordt verwezen naar CFA, Case No 1768 (Iceland), Report nr. 299, juni 1995, par. 110. Zie ook K. Lörcher, Interpretation, in: N. Bruun e.a. (red.), The European Social Charter and the Employment relation, Oxford: Hart Publishing 2017, p. 56-57.

158 ILO Compilation 2018, par. 794. 
geldt dit zelfs voor een 'period of reflection' van veertig dagen. ${ }^{159}$ Ook toelaatbaar is een voorziening bij wet van vrijwillige bemiddeling en arbitrage, 'provided recourse to arbitration is not compulsory and does not, in practice, prevent the calling of the strike'. ${ }^{160}$ Het CFA sluit het opleggen van verplichte bemiddeling niet uit, maar de beslissing daartoe moet liggen bij een onafhankelijke derde. ${ }^{161}$ Verplichte arbitrage wordt door het Deskundigencomité van de ILO aangeduid als 'one of the most radical forms of intervention by the authorities in collective bargaining'. Slechts in een beperkt aantal gevallen is dit acceptabel, onder meer bij essentiële diensten 'in the strict sense of the term'. ${ }^{162}$ Volgens het ECSR mag verplicht(e) arbitrage of bindend advies ${ }^{163}$ uitsluitend worden opgelegd binnen de grenzen van artikel G ESH. In beginsel moet voor ieder geval afzonderlijk worden aangetoond dat hieraan is voldaan. ${ }^{164}$ Verplichte arbitrage is de meest voorkomende reden voor een 'non-conform conclusie' bij artikel 6 lid 3 ESH. ${ }^{165}$ Van vrijwillige arbitrage is slechts sprake indien partijen hier unaniem mee instemmen. ${ }^{166}$ Vermeldenswaard is dat het Europees Hof voor de Rechten van de Mens (EHRM) verplichte arbitrage recent nog door de vingers zag, ondanks dat dit hof het recht op collectief onderhandelen en het recht te staken afleidt van artikel 11 van het Europees Verdrag voor de Rechten van de Mens (EVRM) - dit laatste als

159 ILO Compilation 2018, par. 802.

160 ILO Compilation 2018, par. 793.

161 ILO Compilation 2018, par. 796-798. Zie ook CFA, Case nr. 2905 (Netherlands), Report nr. 365, november 2012; JAR 2012/316, TRA 2013/52, m.nt. K. Boonstra, par. 1222. Met het aanstellen van de bemiddelaar/verkenner gaf de regering gehoor aan de motie-Verhoeven/Schaart (Kamerstukken II 2010/11, 29502, nr. 37).

162 ILO General Survey 2013, par. 480. Onder 'essentiële diensten' in strikte zin verstaat het Deskundigencomité diensten, waarbij een onderbreking ervan het leven, persoonlijke veiligheid of gezondheid van de hele of een deel van de samenleving in gevaar brengt. Zie ook ILO Compilation 2018, par. 816-817.

163 Zie over het onderscheid tussen arbitrage en bindend advies P.E. Ernste, De rol van bindend advies naast arbitrage, TVA 2012/72.

164 Conclusions 2018, Norway, Article 6, par. 4. Zie echter Conclusions 2004, Norway, Article 6, par. 4, waarin het ECSR heeft bepaald dat Noorwegen gevallen van verplichte arbitrage in sectoren die prima facie vallen onder artikel G ESH, niet langer hoeft te melden. Zie ook Conclusions XIV-1, Iceland, Article 6, par. 4 (non-confom); Conclusions 2006, Portugal, Article 6, par. 3 (nonconform); Conclusions 2016, Malta, Article 6, par. 3. Ook kan verplichte arbitrage een inbreuk vormen op artikel 6 lid 2 en 3 (Dorssemont 2017, p. 263-264).

165 Bijvoorbeeld Conclusions XVI-1, Norway, Article 6, par. 3 (non-conform); Conclusions 2010, Albania, Article 6, par. 3 (non-conform); Conclusions 2014, Portugal, Article 6, par. 3 (nonconform); Conclusions 2018, Moldova, Article 6, par. 3 (non-conform); Conclusions 2018, Malta, Article 6, par. 3 (non-conform).

166 Bijvoorbeeld Conclusions XV-1, Malta, Article 6, par. 2. Zie ook Dorssemont 2017, p. 264. 
'the most powerful instrument to protect occupational interest of its members'. ${ }^{167,168}$

\subsection{Voorziening bij wet}

Een actie die niet is voorafgegaan door een verzoenings- of bemiddelingspoging, valt niet buiten de reikwijdte van artikel 6 lid 4 ESH. ${ }^{169}$ Toch bleek hiervoor dat de vakbonden vrezen dat een arbitrage- of bemiddelingsvoorziening afbreuk doet aan het recht op collectieve actie. Is deze vrees gegrond? Hoe gaat de rechter bij de beoordeling van de rechtmatigheid van een collectieve actie om met de AACoptie en een bemiddelings-/arbitrageclausule in de cao? Bij de AAC-optie kunnen drie situaties worden onderscheiden: (1) de situatie dat partijen hebben besloten de gang naar de AAC te maken, (2) de situatie dat partijen (nog) niet hiertoe hebben besloten, en (3) de situatie dat er een advies van de AAC is verkregen.

De eerste situatie was aan de orde bij het geschil met de luchtverkeersleiders op Schiphol, die bij de bespreking van de AAC in de rol van bemiddelaar ter sprake kwam (zie paragraaf 2.3.2). Bijzonder aan dit geschil is dat ook de rechter erbij werd betrokken. Daags na inschakeling van de AAC deed de president van de rechtbank Haarlem uitspraak in een kort geding dat was aangespannen om een einde te maken aan de collectieve ziekmeldingen, die het luchtverkeer grotendeels lamlegden. De president constateerde dat de collectieve actie niet was ingezet als ultimum remedium, aangezien de gang naar de AAC nog openstond, waartoe in deze zaak zelfs al was besloten. ${ }^{170}$ Becking maakte hieruit op dat het inroepen van de AAC niet geheel vrijblijvend was. ${ }^{171}$ Anno 2020 valt hier tegenin te brengen dat naleving van deze spelregel niet langer geldt als zelfstandige voorwaarde voor de rechtmatigheid van de actie. Bovendien was in dit specifieke geval door beide partijen besloten om advies te vragen aan de AAC.

Andere uitspraken die zien op samenloop van de AAC-procedure met een collectieve actie zijn mij niet bekend. In de tweede situatie, namelijk het geval dat nog geen advies of arbitrage is verzocht, wordt blijkbaar (terecht) stilzwijgend aangenomen dat de enkele mogelijkheid daartoe niet afdoet aan het recht om

167 EHRM 27 november 2014, 36701/09 (Hrvatski liječnički sindikat/Kroatië); EHRC 2015/53, m.nt. F. Dorssemont, par. 59. Het EHRM beschouwt het recht op collectief onderhandelen als essentieel element van de vrijheid van vakvereniging (EHRM (Grote Kamer) 12 november 2008, 34503/97 (Demir and Baykara/Turkey); het recht te staken als belangrijk element (EHRM 21 april 2009, 68959/01 (Enerji Yapi Yol Sen/Turkije); EHRM 20 november 2018, 44873/09 (Ognevenko/Rusland); EHRC 2019/49, m.nt. F. Dorssemont)).

168 EHRM 15 mei 2018, 2451/16 (Association of Academics/IJsland); EHRC 2018/184, m.nt. F. Dorssemont. In dit specifieke geval achtte het Hof het opleggen van verplichte arbitrage 'necessary in a democratic society', omdat er, met name door de stakingen in de gezondheidszorg, sprake was van een ernstige bedreiging van het recht op bescherming van de gezondheid (par. 29-30). Zie ook EHRM 27 juni 2002, 38190/97 (Federation of Offshore Workers' Trade Unions and others/Noorwegen) (niet-ontvankelijk).

169 Dorssemont 2017, p. 263.

$170 \mathrm{Rb}$. Haarlem (pres.) 25 mei 1985, KG 1985, 184. Voor de publieke sector is op rechtspraak.nl gezocht op '6 lid 4 ESH'/'staking' en 'handvest' in combinatie met 'mediation'/'bemiddeling'/ 'arbitrage'/'advies- en arbitragecommissie'. De besproken uitspraak is evenwel gevonden in de literatuur.

171 Becking 1992, p. 451. 
collectieve actie te voeren. ${ }^{172}$ Wat betreft de derde situatie (de mogelijkheden ná advies van de AAC) meent Groot, kort gezegd, dat wanneer de AAC zich op grond van juridische argumenten uitspreekt ten voor- of ten nadele van de centrales, dit een daaropvolgende collectieve actie onrechtmatig maakt. ${ }^{173}$ Dit lijkt mij onjuist. Anders dan een arbitrale uitspraak is een advies van de AAC niet bindend, ook niet indien het is gebaseerd op juridische argumenten. ${ }^{174}$ Indien het voortgezette overleg niet leidt tot overeenstemming én daadwerkelijk sprake is van een belangentegenstelling, staat het advies een collectieve actie niet in de weg. Dat zou immers een te grote inbreuk op het recht op collectieve actie betekenen, zeker ook omdat partijen zich eenzijdig tot de AAC kunnen wenden: in dat geval verwordt het de facto tot een eenzijdig bindend advies. Dat is, zoals hiervoor gebleken, in strijd met het collectief actierecht van artikel 6 lid 4 ESH. Uit het voorgaande kan worden afgeleid dat een voorziening bij wet de uitoefening van het collectief actierecht slechts kan beperken indien partijen samen - uit vrije wil hebben afgesproken hier gebruik van te maken en de derdeninterventie nog niet heeft plaatsgevonden.

\subsection{Verwezenlijking bij cao}

Geldt hetzelfde voor een voorziening bij cao? ${ }^{175}$ In de jurisprudentie zijn enkele gevallen te vinden waarin werkgevers aanvoeren dat de staking niet wordt ingezet als ultimum remedium omdat nog geen bemiddelingspoging is gedaan. Over het algemeen blijft dit 'creatieve standpunt'176 zonder succes, ook vóór het Amstaarrest, omdat in Nederland nu eenmaal geen verplichting bestaat tot bemiddeling. ${ }^{177}$ Bij de analyse van de jurisprudentie moet een splitsing worden gemaakt tussen cao-clausules waarin partijen de intentie uitspreken tot derdeninterventie en die waarin partijen zich hiertoe verplichten.

\subsubsection{Intentie tot derdeninterventie}

In de hiervoor aangehaalde uitspraak van 11 augustus 2016 deed KLM een beroep op artikel 13.3 van de cao KLM Grondpersoneel, een intentie tot derdeninterventie, en stelde dat de actie niet gold als ultimum remedium. Onder verwijzing naar het Amsta-arrest merkte de voorzieningenrechter op dat dit thans een gezichtspunt is bij de beoordeling van de vraag of de actie kan worden beperkt of verboden op grond van artikel G ESH, om hier verder niet meer op terug te

172 Stekelenburg 1999, p. 192.

173 C.R. de Groot, De advies- en arbitragecommissie en het recht, SMA 1988/4, p. 282-283.

174 Zie ook Hof 's-Hertogenbosch 31 januari 2012, ECLI:NL:GHSHE:2012:BV2621, r.o. 5.12; Rb. Zeeland-West-Brabant 20 november 2017, ECLI:NL:RBZWB:2017:7596; Rb. Limburg 23 december 2016, ECLI:NL:RBLIM:2016:11262.

175 Voor marktsector is op rechtspraak.nl gezocht op '6 lid 4 ESH'/'staking' en 'handvest' in combinatie met 'mediation'/'bemiddeling'/'arbitrage'.

176 E.M.Y. Sørensen \& K.G. Kapel, annotatie bij Rb. Midden-Nederland 30 december 2014, ECLI:NL:RBMNE:2014:7163, par. 7.

177 Rb. Midden-Nederland 30 december 2014, ECLI:NL:RBMNE:2014:7163, r.o. 4.10, JIN 2015/52, m.nt. E.M.Y. Sørensen en K.G. Kapel, JAR 2015/32, m.nt. E. Loesberg; Rb. Utrecht 11 april 2003, ECLI:NL:RBUTR:2003:AF7224, r.o. 4.10; Rb. Utrecht 11 april 2003, ECLI:NL:RBUTR: 2003:AF7225, r.o. 4.10. 
komen. De actie werd (ook in hoger beroep) verboden vanwege 'de explosieve combinatie' van de te verwachten grote vakantiedrukte en de terreurdreiging van dat moment. ${ }^{178}$ In zijn bijbehorende annotatie noemt De Laat als mogelijk gevolg van het gebrek aan de in artikel 6 lid 3 ESH bedoelde voorzieningen in Nederland dat de rechter bij collectieve acties zonder bemiddeling vooraf 'niet al te snel een afkoelingsperiode dient te gelasten' ${ }^{179}$ Echter, in deze zaak was juist wél voorzien in een geschillenclausule in de cao. Een andere benadering koos de voorzieningenrechter van de rechtbank Haarlem bij een voorgenomen actie van Transavia-vliegers in 2008, dus nog vóór het Amsta-arrest. Hij legde veel nadruk op de in aanmerking te nemen belangen (van derden) en de aanzienlijke schade die Transavia van een staking had te duchten. Partijen waren daarom ten onrechte voorbijgegaan aan artikel 13.3: '[V]an partijen [dient] te worden gevergd dat zij binnen redelijke grenzen het uiterste beproeven om de tussen hen bestaande verschillen aan de onderhandelingstafel tot een oplossing te brengen en dus niet voortijdig te grijpen naar collectieve pressiemiddelen.' Het stakingswapen kon voorlopig in de 'ijskast'. 'Dat kan anders komen te liggen indien ook onderhandelingen onder leiding van een derde-bemiddelaar of andere substantiële minnelijke pogingen niet op relatief korte termijn reëel uitzicht gaan bieden op volledige oplossing van het conflict', besloot de voorzieningenrechter. ${ }^{180}$ Reeds vóór het Amsta-arrest riep dit oordeel de vraag op of, in de woorden van Verburg, 'de rechter niet te veel op de stoel van de partijen was gaan zitten'. ${ }^{181}$

Naar de huidige stand van de stakingsjurisprudentie lijkt mij de juiste koers om een 'intentie-tot-bemiddelingsclausule' als artikel 13.3 te betrekken bij de proportionaliteitstoets, en wel als onderdeel van de vraag of de actie is ingezet als ultimum remedium. Volgens de Hoge Raad kan aan dit gezichtspunt onder omstandigheden zelfs beslissende betekenis toekomen. ${ }^{182}$ Dit kan er mijns inziens toe leiden dat de kortgedingrechter, onder verwijzing naar artikel 6 lid $3 \mathrm{ESH}$, een verplichte afkoelingsperiode oplegt. Op zich kan deze lijn worden doorgetrokken naar een voorziening bij wet, alsmede de mogelijkheid tot ad hoc derdeninterventie. Zelfs voor de algemene stelling van Jacobs, dat de rechter het oordeel over de rechtmatigheid van stakingen die derden ernstige schade berokkenen moet opschorten in afwachting van de uitkomst van bemiddeling of arbitrage, valt iets te zeggen, mits de verplichte derdeninterventie de toets aan artikel G ESH weet te doorstaan. ${ }^{183}$ Toch zou ik een cao-bepaling meer gewicht willen toekennen bij de

178 Rb. Noord-Holland 11 augustus 2016, ECLI:NL:RBNHO:2016:6696, JAR 2016/208, m.nt. A. Stege, r.o. 4.7. Zie ook Hof Amsterdam 26 augustus 2016, ECLI:NL:GHAMS:2016:3472, TRA 2016/95, m.nt. J.J.M. de Laat, JIN 2016/186, m.nt. A.M.W. van Vlodrop, JAR 2016/229, m.nt. A. Stege.

179 J.J.M. de Laat, Staken op Schiphol: over safety, (national) security en pressing social need, annotatie bij Hof Amsterdam 26 augustus 2016, ECLI:NL:GHAMS:2016:3472, TRA 2016/95.

180 Rb. Haarlem 25 augustus 2008, ECLI:NL:RBHAA:2008:BE9210.

181 Verburg 2017, par. 3.

182 HR 19 juni 2015, ECLI:NL:HR:2015:1687, r.o. 3.3.5 (Amsta).

183 Jacobs 2017, p. 83, 141. Zie ook A.T.J.M. Jacobs, Post-industrieel stakingsrecht, SMA 1991, p. 672. 
proportionaliteitstoets, omdat cao-partijen deze afspraak nu eenmaal zelf hebben gemaakt.

\subsubsection{Verplichting tot derdeninterventie}

Dit geldt temeer indien de cao-partijen opteren voor pseudo-vrijwillige derdeninterventie. Uit de zinsnede 'behoudens verplichtingen uit hoofde van reeds eerder gesloten collectieve arbeidsovereenkomsten' in artikel 6 lid 4 ESH volgt dat partijen zelf een procedurele beperking kunnen verbinden aan de uitoefening van het recht op collectieve actie. Dit geschiedt door het opnemen van een vredesplichtclausule. ${ }^{184}$ Dit verklaart dat de voorzieningenrechter van de rechtbank Midden-Nederland bij een voorgenomen staking bij Buigcentrale Steenbergen (een staalproducent) helemaal niet toekwam aan een toetsing aan artikel G ESH. In dit geval was er strijd met het stakingsverbod van artikel 10.3 van de cao Metalelektro 2015-2018, welke cao eerder aan de orde kwam in paragraaf 3.2.2.2. ${ }^{185}$ Anders dan de cao-partijen in de luchtvaartsector hebben partijen zich in deze cao min of meer verplicht tot bemiddeling: het stakingsverbod vervalt uiterlijk vier weken na de datum waarop aan de Bemiddelingsinstantie voor de Metalelektro een verzoek om bemiddeling en/of beoordeling is gedaan of zodra deze een uitspraak heeft gedaan. ${ }^{186}$ Kort gezegd was in dit geval de periode van vier weken nog niet verstreken. Dat een rechter partijen zonder meer houdt aan een bemiddelingsafspraak, is opmerkelijk in het licht van het oordeel van de Hoge Raad ten aanzien van de mediationovereenkomst ${ }^{187}$ tussen particulieren: 'Gelet op de aard van het middel van mediation staat het beide partijen te allen tijde vrij hun medewerking daaraan alsnog te onthouden, dan wel die om hen moverende redenen te beëindigen.' ${ }^{188}$ Bemiddeling moet in beginsel vrijwillig en vrijblijvend zijn, zoals ook de ILO-toezichthouders voorstaan. ${ }^{189}$ Aan de andere kant raakt het passeren van een bemiddelingsafspraak hier niet alleen partijen zelf, maar ook derden indien het alternatief een staking is. Mede in dit licht vind ik het alleszins begrijpelijk dat de rechtbank Midden-Nederland zwaar tilde aan de vredesplicht-

184 Zie ook Van Drongelen \& De Jong 2014, par. 3.4; ESH Digest 2018, p. 106.

185 Thans opgenomen in artikel 7.7.1 cao Metalelektro 2018-2020.

186 Rb. Midden-Nederland 17 november 2017, ECLI:NL:RBMNE:2017:5846. Thans opgenomen in artikel 7.9.1 t/m 7.9.4 en bijlage E cao Metalelektro 2018-2020.

187 Schonewille geeft de volgende definitie voor mediation in (echt)scheidingszaken: 'Mediation is een gefaseerde methode van bemiddeling in een conflict of geschil waarbij een neutrale deskundige - de mediator - het conflict of geschil samen met partijen diagnosticeert en vervolgens de onderhandelingen tussen partijen faciliteert en begeleidt, teneinde vanuit hun werkelijke belangen tot gezamenlijk gedragen, duurzame oplossingen te komen - op basis van zelf geformuleerde normen en/of rechtsnormen die worden vastgelegd in een vaststellingsovereenkomst als bedoeld in art. 7:900 e.v. BW' (C.A.R.M. van Leuven \& F. Schonewille, Gelukkig getrouwd, gelukkig gescheiden, Deventer: Wolters Kluwer 2018, par. 11.1.2).

188 HR 20 januari 2006, ECLI:NL:HR:2006:AU3724. Zie ook A.M.L. Broekhuijsen-Molenaar, Mediation: vrijwillig of afdwingbaar?, NJB 2019/1200. Zie ook Rb. Utrecht 11 april 2003, ECLI:NL:RBUTR:2003:AF7225, r.o. 4.10: 'In beginsel is een vakvereniging niet gehouden om een aanbod tot bemiddeling van de zijde van de werkgever te accepteren. Dit zou slechts anders zijn indien van bijzondere feiten en/of omstandigheden sprake is.'

189 ILO Compilation, par. 1325 e 1326. Zie ook CFA, Case nr. 2905 (Netherlands), Report nr. 365, november 2012, par. 1222, JAR 2012/316, TRA 2013/52, m.nt. K. Boonstra. 
clausule. Vanuit het oogpunt van de vakbonden is dit alles bepaald geen reclame voor een bemiddelings- en/of arbitrageclausule.

\section{$5 \quad$ Afsluiting}

Per 1 januari 2020 is de AAC voor de genormaliseerde overheidssectoren getransformeerd tot een cao-voorziening. Een dergelijke bemiddelings- en/of arbitrageclausule is zeker niet gebruikelijk in de marktsector en het is maar de vraag of deze behouden blijft naarmate de ambtelijke cao's meer zullen 'ontambtelijken'. Het beeld ontstaat dat de cao-partijen in de marktsector bepaald niet warmlopen voor derdeninterventie bij collectieve conflicten, terwijl dit in de publieke sector tot dusver met een zekere regelmaat voorkwam. Toch zijn er goede argumenten voor (de terugkeer van) een wettelijke voorziening, ook naast artikel 6 lid 3 ESH. Voor de cao-partijen zelf kunnen negatieve publiciteit bij acties en een steeds beperktere stakingsbereidheid van werknemers reden zijn om op zoek te gaan naar andere manieren om het geschil te beëindigen. ${ }^{190}$ Daartoe kunnen partijen natuurlijk kiezen voor een voorziening bij cao, maar daarmee beperken zij zichzelf in de uitoefening van het collectief actierecht, zelfs indien zij slechts een intentie tot derdeninterventie uitspreken. Een rechter zal in dat geval eerder geneigd zijn deze te betrekken bij het ultimum remedium-criterium, dat via de proportionaliteitstoets nog steeds een rol speelt in de Nederlandse stakingsjurisprudentie. Het door de wetgever bevorderen van de mogelijkheid van bemiddeling is bovendien in het publiek belang. Dit geldt temeer bij dreigende acties bij essentiële diensten. Bij een dreigende escalatie draait het conflict niet meer uitsluitend om de belangen van de cao-partijen, maar ook om die van derden die door een collectieve actie schade kunnen ondervinden. Daarom ben ik voorstander van herinvoering van de wettelijke grondslag voor de procedure bij de AAC. In ieder geval acht ik dit wenselijk voor sectoren die essentiële diensten leveren, zowel in de publieke als in de private sector. In aansluiting hierop zou ik zelfs nog een stap verder willen gaan door ook in de marktsector hierbij aan te sluiten, ofwel door een met de AAC vergelijkbare instantie in te stellen, ofwel door het werkgebied van de AAC uit te breiden - 'omgekeerde normalisering' dus. ${ }^{191}$

Wel zie ik aanleiding om te onderzoeken hoe de AAC of een vergelijkbare instantie het beste kan worden ingericht, aangezien er aanwijzingen zijn dat de AAC lang niet altijd wordt ingeroepen bij echte cao-conflicten. Een aanbod van verschillende vormen van derdeninterventie, waarvan partijen - vrijwillig en vrijblijvend - gebruik kunnen maken, komt het meest tegemoet aan de kritiek op enkele voorzieningen uit het verleden. Het gaat daarbij om 'een facilitair bedrijf dat op afroep van partijen ter beschikking staat', niet meer en niet minder. ${ }^{192}$ Ook doe ik een beroep op de rechter om - artikel 6 lid 3 ESH indachtig - bij de beoordeling

190 Loonstra 1993, p. 31; Jacobs 2018, par. 7.1.

191 Zie ook W.S.P. Fortuyn, Final-offer arbitrage: een zinvol instrument voor de oplossing van arbeidsgeschillen in de collectieve en de particuliere sector, in: K.M. Becking, Final-offer arbitrage, Den Haag: CAOP 1991, p. 65-66; Albeda 1989, p. 169.

192 Van Voorden 1991, p. 664. 
van de rechtmatigheid van een collectieve actie in het kader van het ultimum remedium-gezichtspunt acht te slaan op de mogelijkheid tot derdeninterventie en, binnen de grenzen van artikel G ESH, de mogelijkheid om een afkoelingsperiode te gelasten niet langer onbenut te laten. Tot slot zij vermeld dat ik derdeninterventie geenszins wil overschatten: niet ieder cao-conflict kan hiermee worden opgelost. ${ }^{193}$ Ook kan dit de collectieve actie nimmer vervangen: de dreiging van een collectieve actie is een wapen op zich. ${ }^{194}$ Wel meen ik dat er reden is om het derde lid van artikel 6 ESH niet te 'vergeten'. 